Document downloaded from:

http://hdl.handle.net/10251/124276

This paper must be cited as:

Lo-lacono-Ferreira, VG.; Capuz-Rizo, SF.; Torregrosa López, JI. (2018). Key Performance Indicators to optimize the environmental performance of Higher Education Institutions with environmental management system - A case study of Universitat Politècnica de València. Journal of Cleaner Production. 178:846-865. https://doi.org/10.1016/j.jclepro.2017.12.184

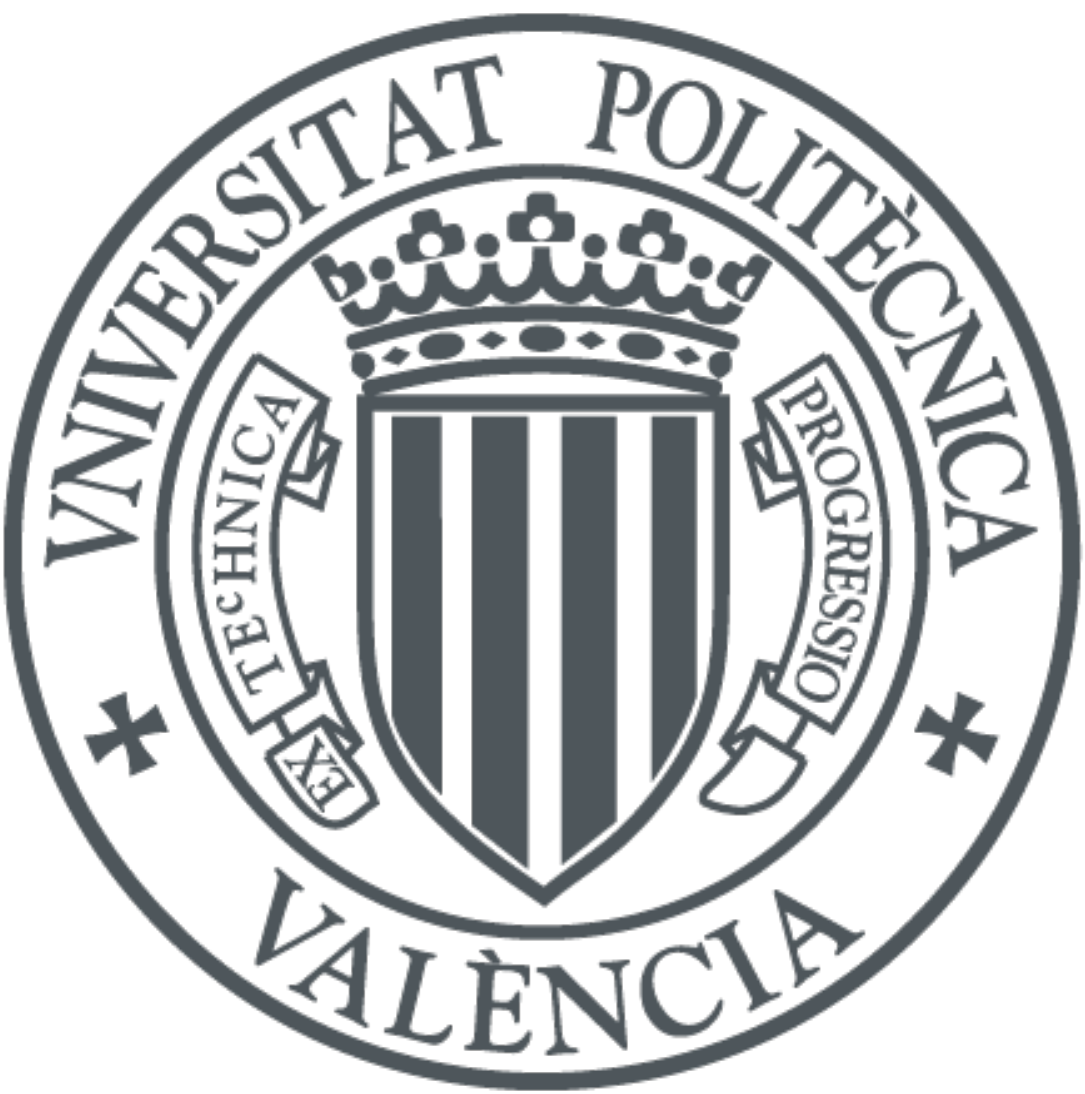

The final publication is available at

http://doi.org/10.1016/j.jclepro.2017.12.184

Copyright Elsevier

Additional Information 


\title{
Key Performance Indicators to optimize the environmental performance of Higher Education Institutions with EMS. Case study of Universitat Politècnica de València.
}

\begin{abstract}
The environmental performance has been gaining place in the decision makers board of organizations. Higher Education Institution with environmental awareness required, as all organizations, tools to help the development of policies and programs toward a better performance.

Key Performance Indicators are usually part of economic and financial decision-maker boards. The definition of a set of Key Performance Indicators regarding the relevant environmental aspects of an institution seems to be a step toward the integration of environmental issues in the overall management.

In this paper, a methodological proposal to define environmental Key Performance Indicators for Higher Education Institutions with robust Environmental Management System (ISO certified or EMAS verified) is proposed together with a validation system based on Metaperformance evaluation indicators. The proposal is based on the significant environmental aspects along with the degree of operational control that the organization has over them. Additionally, a list of over 140 environmental indicators described and classified are offer as inspiration.

An environmental unit, EPSA, of Universitat Politècnica de València, EMAS verified, is used as a pilot case study. As a result, seven Key Performance Indicators are defined, although only three could be fully assessed. Energy consumption, waste management treatment and greenhouse gases emissions are the key elements of these indicators.

Institutions with robust Environmental Management Systems have significant advantages on the identification of the relevant environmental aspects and the definition of the goals that set the start point to define Key Performance Indicators. However, these systems do not ensure the availability of data or the quality desired. In the case study, additional resources are required in order to obtained results for the Key Performance Indicators that assess it significant environmental aspects. The effort would benefit both the Environmental Management System and the decision-making board.
\end{abstract}

\section{Keywords}

Higher Education Institution; Key Performance Indicator; Environmental Indicators; Environmental performance; Environmental Management System.

\section{Highlights}

- Use of KPIs as tool to improve the environmental performance of HEIs.

- EMAS framework serves as guide for the definition of KPIs.

- Energy consumption, waste management and GHG are key aspects to assess on HEIs.

- Build-up area is the functional unit suggested for HEIs KPIs

- Full-time equivalent student and employees are the reporting units suggested. 


\author{
Abbreviations \\ AASHE: Association for the Advancement of Sustainability in Higher Education \\ CC: Complete Control \\ $\mathrm{CO}_{2} \mathrm{e}$ : Carbon Dioxide equivalent. \\ CS: Control State \\ EA: Environmental Aspects \\ EAS: Environmental Aspects State \\ EMAS: Eco-Management and Audit Scheme \\ EMS: Environmental Management System \\ EPIs: Environmental Performance Indicators \\ EPSA: Higher Polytechnic School of Alcoy (Escuela Politécnica Superior de Alcoy in Spanish) \\ EU: Environmental Unit \\ FTE: Full-time equivalent \\ GHG: Greenhouse Gases \\ GRI: Global Reporting Initiative \\ HEIs: Higher Education institution \\ ISO: International Standard Organization \\ KPIs: Key Performance Indicators \\ NS: Insignificant \\ PC: Partial Control \\ PIs: Performance Indicators \\ S: Significant \\ STARS: Sustainability Tracking, Assessment \& Rating System \\ UC: Uncontrolled \\ UPV: Universitat Politècnica de València
}

\title{
1 Introduction
}

Many organizations seek ways to understand, communicate and improve their environmental performance. This can be achieved by effectively managing those elements of their activities, products and services that can significantly impact the environment (International Organization for Standardization, 2013). Higher education institutions (HEIs) are not an exception. The number of HEIs aware of their environmental impact has increase in the last decades. As in any enterprise, an environmental management system (EMS) can by launched at a HEI. There are several examples with different degrees of involvement and commitment, e.g. Gustavo de lima et al., (2016), Hancock and Nuttman, (2014) and Lozano et al. (2014). The communication and reporting of performances and strategies related either to environment or to the whole sustainability package have also emerged. However, the communication does not necessarily mean that the organization is doing its best (Beloff et al., 2004).

Although activities, products and services are not as easy to identify as in industrial or services companies, they are part of daily operation of a HEI. Qualify students, expert teachers and successful researchers can be seen as HEIs products along with patents and startups generated as a result of their activities. HEIs frequently provide services to companies and governments on those issues where they have expertise. All these actions are articulated through a large number of management, research, teaching and development activities. Assessing the environmental performance of these activities is the key for having a HEI as environmentally responsible as possible toward its sustainable development (Disterheft et al., 2012).

Traditional environmental assessments of HEIs encompass both three activities (teaching, researching and transferring technology services) probably because their individual impacts are difficult to allocate. The simplest systems are limited to treat the information available, without major efforts to expand this information. Results can be useful, in some way, to assess the evolution of those aspects studied. HEIs with resources and certain environmental degree has a dedicated office with an EMS (certified or verified) to manage and assess environmental issues related to their activity. Cons of these systems are widely known; e.g. lack of detailed 
information, replicate issues, etc. in essence, lack of standardization (Mazzi et al., 2012; Torregrosa-López et al. 2016).

For a successful management (including the definition of environmental policies), managers need information about the performance and tendencies of the organization (Azma, 2010; Bauler, 2012). There are many ways to get information. Their efficiency depends on the type of organization and the use of the information. Aggregate indicators, for example, compiles data on a single index. The aggregation of data on a single index might increases the risk of losing relevant information (Alam et al., 2016). Ecological Footprint can be an example of a single index where the result is skewed by the criteria followed though the assessment beside other considerations (Lambrechts and Van Liedekerke, 2014; Lo-Iacono-Ferreira et al., 2016a). Other technics are available to aggregate information. Multi-criteria analysis has proven to be useful in aggregation although evaluators need to make some choices adding uncertainty to the assessment. Initiatives combining tools were developed trying to solve some of the problems that traditional EMS has. For example, the combination of different management tasks as life cycle assessment (LCA), multi-criteria analysis and performance indicators trying to solve the lack of detailed information (Hermann et al., 2007). Nevertheless, having accurate environmental information shouldn't be a problem if there is a well-developed EMS.

Performance Indicators (PIs) are goal-related indicators that includes the reference point needed for its evaluation (Barnetson and Cutright, 2000). They indicate if targets will be met and shad light over the requirement of additional measures. According to ISO 14031 (International Organization for Standardization, 2013) environmental PIs provide data and information about the organization's environmental performance. These indicators can be classified in two types: (a) operational performance indicators, which provide environmental performance information on the operation of the production or service processes develop by the organization, and (b) managerial performance indicators which provide information efforts that influence positively the environmental performance of the organization (Perotto et al., 2008).

Performance indicators must have certain characteristics and properties to be considered in order to ensure usability, comparability and consistency (Bonaccosi et al., 2007; Bauler, 2012; ISO, 2013):

- Intelligible: Meaning and theoretical terms should be clear and well-defined.

- Useful: Procedures must be exhaustively defined in order to ensure comparability even if it is an indicator for internal use only. Indicators must be easy to measure and easy to apply.

- Standardized: A standardization or functional unit is required to give meaning to the indicator. EMAS (European Commission, 2009), for example, propose the ratio input / output; an easy to use standardization for traditional companies with clear outputs. HEIs required additional considerations regarding outputs or results regarding their nature as described above.

- Sensitive: The sensitivity to stresses on the system must be perceptible and the response to stress, predictable.

- Coherent: All PIs must be coherent with the environmental policy of the organization.

- Representative: The environmental performance of the organization must be represented by the set of indicators defined.

Key Performance Indicators (KPIs) are indexes used to evaluate the crucial factors related to a defined goal (e.g. zero waste management system). The success of the organization in achieving this goal depends on these factors. Identifying the crucial factors and follow them up is a way to know how the organization is developing (Kerzner, 2011; Zaman, 2014).

When KPIs are defined, additionally to the properties and characteristics mentioned for PIs, the SMART criteria must be followed ensuring Specific, Measurable, Achievable, Relevant and Timely indicators (Doran, 1981). The set of key indicators should provide coverage of the system having a known response to natural disturbances and changes over time. If these indicators are also environmental indicators, resulting environmental KPIs, its integration in the EMS would provide relevant information about how the organization is managing those crucial factors linked to the environmental performance. As environmental 
indicators, it is advisable that they suite in the DPSIR framework (Drive forces, Pressure, State, Impact, Response) used by organizations as the European Environmental Agency in its reporting activities (Smeets and Weterings, 1999). DPSIR scheme is shown in Fig. 1 where the interactions between each type of indicator can be seen.

- Drive forces indicators represents human influence and natural conditions that drives changes on the environment (population growth).

- Pressures indicators shows the stress that human activities and natural conditions place on the environment (e.g. $\mathrm{CO}_{2}$ emissions).

- State indicators represents the condition of the environment (e.g. Concentration of $\left.\mathrm{CO}_{2}\right)$.

- Impacts indicators shows the effects of environmental changes either biological, economic or social (e.g. percentage of population expose to noise).

- Responses indicators accounts the action or responses of society to the environmental situation (e.g. environmental expenditures).

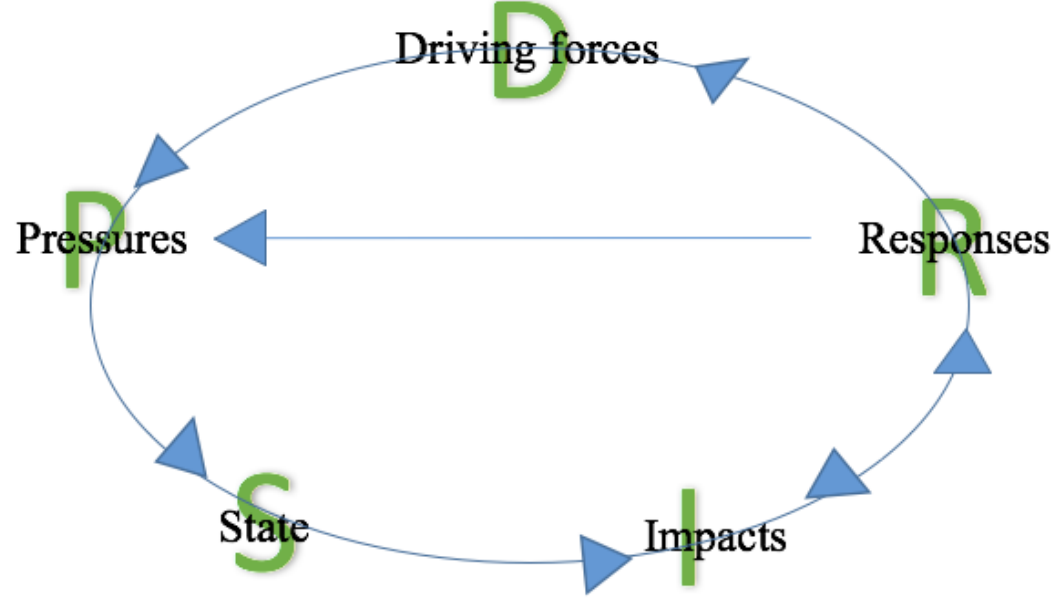

Figure 1. DPSIR framework

In addition to the DPSIR framework, the European Environmental Agency (2014) classifies environmental indicators by $\mathrm{ABCDE}$ typology where:

- Type A are descriptive indicators;

- Type B gathered those indicators that answers the question 'Does it matter?' better known as PIs;

- Type $\mathrm{C}$ are efficiency indicators;

- Type D are policy effectiveness indicators and,

- Type $\mathrm{E}$ are total welfare indicators normally presented by overall measures like the Index of Sustainable and Economic Welfare.

It has to be notices that any Type A indicator can be easily converted into Type B by referring them to target or a reference condition. PIs are relevant when an institution is accountable for changes in environmental pressures or states.

A set of KPIs may be a promising decision-making tool if they represent the main characteristics of the system. Other tools or supplementary information might be needed to address additional goals different for which KPIs were defined for (Hermann et al., 2007; ORGANIZATION FOR ECONOMIC COOPERATION AND DEVELOPMENT, 2000). Added to the usefulness for managers, communicating the appropriate indicators can also benefit the overall status of the HEI (Lukman et al., 2010).

In this paper, a methodology procedure for defining environmental KPIs for HEIs is proposed. Universitat Politècnica de Valènica (UPV) has been chosen has a case study due to its EMS verified in EMAS that has proven to be a valuable source of environmental information regarding HEIs behavior (Lo-Iacono-Ferreira et al., 2016). This work also summarizes the analysis made to define KPIs for one of UPV environmental units (EUs) following the proposed methodology. An environmental unit is a delimitated area with well-defined functions. UPV 
EMS divided the HEI in EUs for a better tracking and management serving as a pilot for this study. The EU chosen is the Higher Polytechnic School of Alcoy -Escuela Politécnica Superior de Alcoy in Spain- (EPSA). The system boundary of this EU is defined further in this paper.

\subsection{Literature review over environmental indicators relevant to HEIs}

There are several tools based in indicators to assess urban sustainability of cities where the environmental performance is included. Campuses have strong similarities to small cities or towns, reason why these indicators deserve consideration (Alonso-Almeida et al., 2015; Wright and Wilton, 2012). Braulio-Gonzalo et al. (2015) carried a depth analysis of these tools including LEED ND, BREEAM Communities, CASBEE UD, ECOCITY, Le Modele INDI-RU 2005, The BRIDGE project, KITCSAP among others.

García-Sánchez et al. (2014) explored the Environmental Performance Indicators (EPIs) for countries in the process of a composite index proposal based on Driving Force-Pressure-StateExposure-Effect-Action (DPSEEA) methodology. A robust and complete method focus on the reduction of the impact of the environment over human health. LCA and multi-criteria analysis are combined with EPIs in COMPLIMENT, a tool designed to assess environmental impact of business (Hermann et al., 2007). During the process, an exhaustive and interesting description of EPIs is made highlighting its strengths and weaknesses as assessment instruments. Later, Hourneaux Jr et al. (2014) studied the real usefulness of EPIs for business. Both studies provide knowledge that can be brought to HEIs with some considerations already studied by Walton and Galea (2006).

The literature on environmental indicators is usually broad and diverse e.g. Moldan et al., (2012) compared a wide number of indicators environmentally related while Singh et al. (2012) overviewed all sustainability assessment methodologies including several environmental composite indexes as the ecological footprint. Furthermore, several handbooks and databases about EPIs definition can be found, e.g. EEA's Indicator Management System (European Environmental Agency, 2016), the Yale Center of Environmental Law \& Policy Practical Guide (Hsu et al., 2013), UNSD (2016), Environmental Indicators by Wild et al. (2015) or the Organization for Economic Cooperation and Development (OECD) handbooks (Organization for Economic Cooperation and Development, 2008, 2012, 2014) that goes beyond generic EIs and focus on key environmental indicators (performance and non-performance indicators). KPIs are commonly applied with economic or financial purposes (e.g. Azma (2010), Serdar (2010)). Regarding standards, in ISO 14031 it can be found a procedure for environmental performance assessment through KPIs (ISO, 2013; Campos et al., 2015). Although HEIs have substantial differences with regular corporations (in size, aim, management structure, etc.), the procedure and outcomes also deserved consideration. Dočekalová and Kocmanová (2016) identified KPIs related to environment along with societal and economic indicators for the sustainability measurement of corporations by analyzing different sustainability reporting and managing tools also included in Braulio-Gonzalo et al. (2015) analysis.

Fernández et al. (2011) applied Bayesian networks to define the relevance of the indicators that better describe the academic performance of a HEI. Barnetson and Cutright (2000) analyzes funding related PIs applied in HEIs, including a rigorous review of voluminous literature related, to develop a typology of assumptions commonly embedded in these types of indicators contesting its objectivity.

The use of environmental indicators in HEIs is extended although they are not defined and/or managed as key indicators. Olszak (2012) study the sustainability assessment of campuses where environmental indicators are included as part of the sustainability concept. Waheed et al. (2011) developed a sustainability indicators-based tool for HEIs using DPSEEA framework where the environment is well represented.

Finally, there are two reporting tools that deserves to be highlighted: (a) Global Reporting Initiative (GRI) a sustainability reporting guidance for any time of organization (Global Reporting Initiative, 2013; Lo-Iacono-Ferreira et al., 2016b) and (b) the Sustainability Tracking, Assessment \& Rating System ${ }^{\text {TM }}$ STARS (The Association for the Advancement of Sustainability in Higher Education, 2016); a self-reporting framework for HEIs to measure their sustainability performance. Both tools include environmental performance indicators as part of 
their reporting process. The main difference between them is the complexity of the indicator; while GRI offers simple indicators, The Association for the Advancement of Sustainability in Higher Education (AASHE) suggests composite indicators that require significant time and resources to be measured.

\subsection{Methods}

To address the aim of this study, developing a methodology to define environmental KPIs for HEIs with a robust EMS, a detailed review of literature has been made. The characteristics of EMS along with the particularities of HEIs has been deeply considered. Over 300 environmental indicators have been analyzed. A description and classification of the environmental indicators applicable to HEIs is presented in Annex 1. These information is used as complementary support for the methodology proposal. The knowledge acquired from the implementation and management of EMS at UPV has served as guidance.

As a result, in section 2, a methodological proposal to define environmental KPIs for HEIs with robust EMS is presented. Section 3 presents the results of applying this methodology to one of the EU of UPV, EPSA, as a pilot. Conclusions and further studies are summarized defined in section 4 .

\section{Methodological proposal}

In order to identify those key indicators to optimize the environmental performance of HEIs that have a robust EMS (either verified in EMAS or simply certified in ISO 14001), a procedure of continuous improvement is suggested. The entire procedure proposed is described in figure 2. Fiksel (2002) states that key indicators should be defined over the needs of the organization on stable basis. In this sense, the first step requires the definition of the reporting organization and its system boundary. If any significant changes are detected in further iterations of the study, the definition has to be updated.

The second step identifies the environmental aspects (EA) considering both the relevance and the level of control that HEI has over the aspect. As a result, those aspects with a clear relation to the environmental performance of the organization will be highlighted.

The definition of goals based on these results is the third stage. Scheme shows a link to a highly recommended procedure, the consulting of stakeholders. The relevance of this protocol is discussed further in this paper.

Goals will serve as framework for the forth step: the definition of KPIs. The definition of environmental KPIs shall be based in the list of environmental aspects and the specific goals previously described.

Once KPIs are defined, managers can integrate the set of environmental KPIs in the management system together with the other KPIs. The definition of targets, a policy development, the implementation of an action plan and the analysis of the degree of compliance are foreseen and are not within the scope of this study.

A report is expected to improve the synergies between the top-management of the HEI and the EMS. The time period of each KPI and, therefore, its next evaluation is strongly related to the targets and actions plans defined. However, as KPIs are pretended to be also fully integrated in the EMS, an annual assessment as part of the annual review of the EMS is suggested. Regarding the continuous improvement cycle, will start with the update of the register of environmental aspects. 


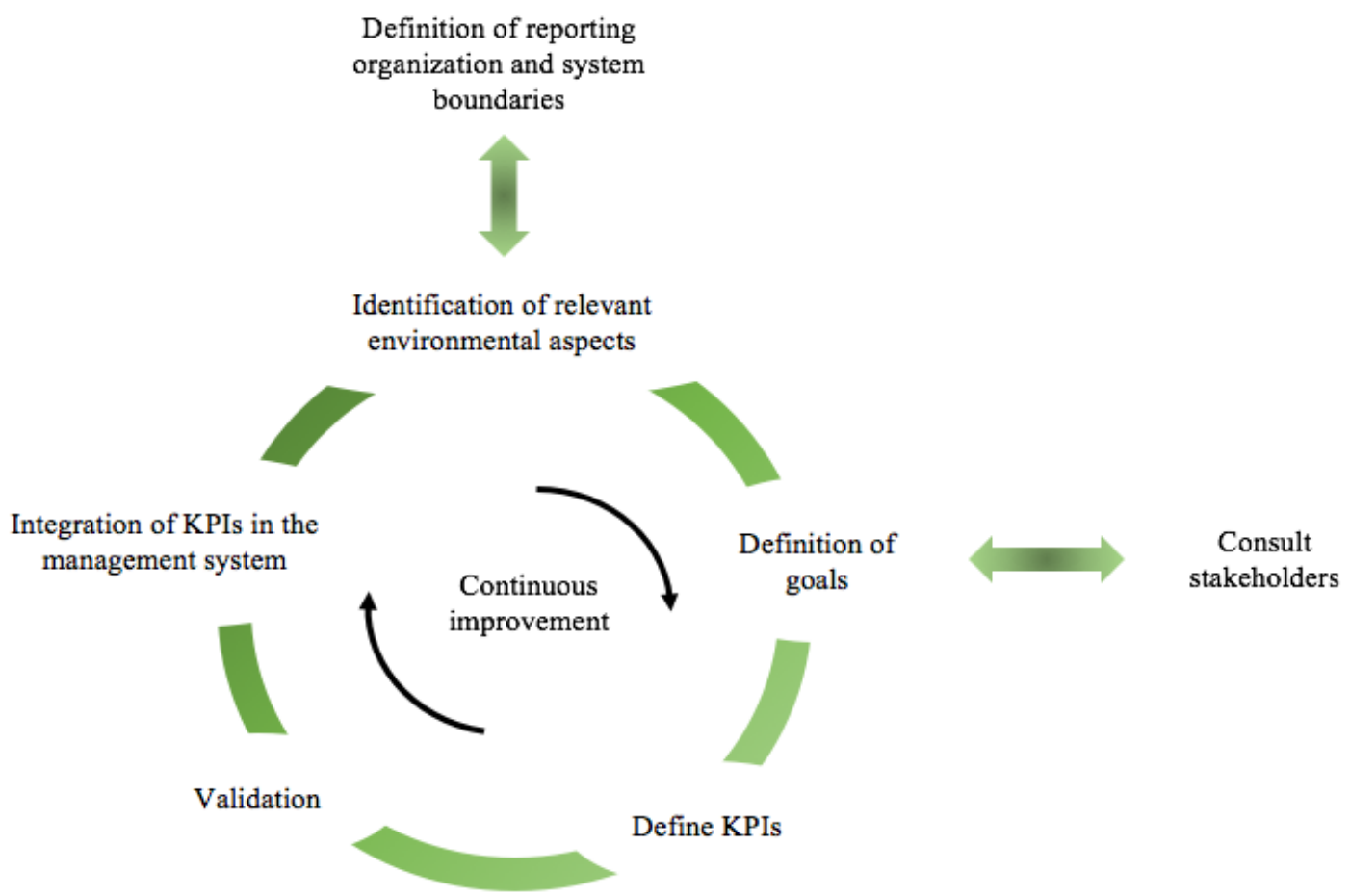

Figure 2. Methodological procedure proposal for the definitions of environmental KPIs for HEIs with EMS.

The identification of relevant aspects, the determination of goals and the definition of KPIs are described further in this section. The definition of KPIs includes the definition of a reporting organization and a validation procedure. The analysis of the EIs gathered in the literature review along with its classification is also included as a tool for the KPIs definition step.

The synergies between the methodological proposal and the characteristics of EMS verified in EMAS or certified in ISO are highlighted when applicable.

\subsection{Definition of reporting organization}

The methodology requires the definition of reporting organization to describe the organization whose environmental performance want to be optimize. ISO 14072:2014 offers a guide to unambiguously state the organization to be studied, the reporting organization, its scope and system boundary. The definition of the reporting organization has to be completed with the specification of the activities and processes that takes place within the scope of the reporting organization. Following ISO 14072 standard ensure a life cycle point of view to this procedure that enriches the environmental management and builds bridges between well-recognized tools as LCA. The general goal of the study is already pre-defined - the optimization of the environmental performance of the organization - as it is the motivation of this methodological proposal.

The definition of system boundaries shall be based on Braunschweig (2014) proposal as an extension of the GHG Protocol Corporate Standard (WRI and WBCSD, 2011):

- Scope 1 for direct emissions, resources use and waste generation,

- Scope 2 for indirect emissions, resources use and waste generations associated, exclusively, with infrastructure usage,

- Scope 3 for all other indirect emissions, wastes and resources used

Complex organizations as HEIs might be difficult to assess as a whole moreover when human and economic resources are limited. For these cases, the environmental unit (EU) is suggested as a reporting organization. The EU is a physically defined area with operational control of, at least, one operation (process or activity). Although it is not a standardized concept, it has been validated during the EMAS verification of the EMS of UPV in 2009.

Any HEI can be divided in independent EUs with the proper definition. However, special care has to be taken to avoid double assignment of operations and impacts. The environmental 
reviews, mandatories for EMAS, requires a deep description of the organization itself to identified environmental impacts and legal requirements that makes the definition of EU a simple step.

As a result of this first step, assessors should document the definition of the reporting organization including:

- Description of the HEI (size, infrastructure, number of students and employees, etc.),

- System boundary definition,

- Description of HEI's operations: activities and processes that takes place within the scope defined.

The definition of the reporting organization shall be reviewed and rectified if any significant changes take place within the system boundary defined.

\subsection{Identification of relevant environmental aspects}

The second step is to identified and prioritized the EA of the reporting organization. This step is easy to address in HEIs with EMS verified in EMAS, or certified in ISO 14001, as the identification of EA is a requirement during its implementation process. Additionally, the regular environmental review required by EMAS to identify and assess any new EA ensure that the list of EA is always up to date.

In previous studies, a prioritization procedure to assigned resources and efforts for the collection of data of EA has been developed (Lo-Iacono-Ferreira et al., 2017). The procedure considers the significance of each EA (Environmental Aspect State -EAS) and the level of operational control that the reporting organization has over the aspect, the Control State (CS). The scheme of the procedure is shown in figure 3.

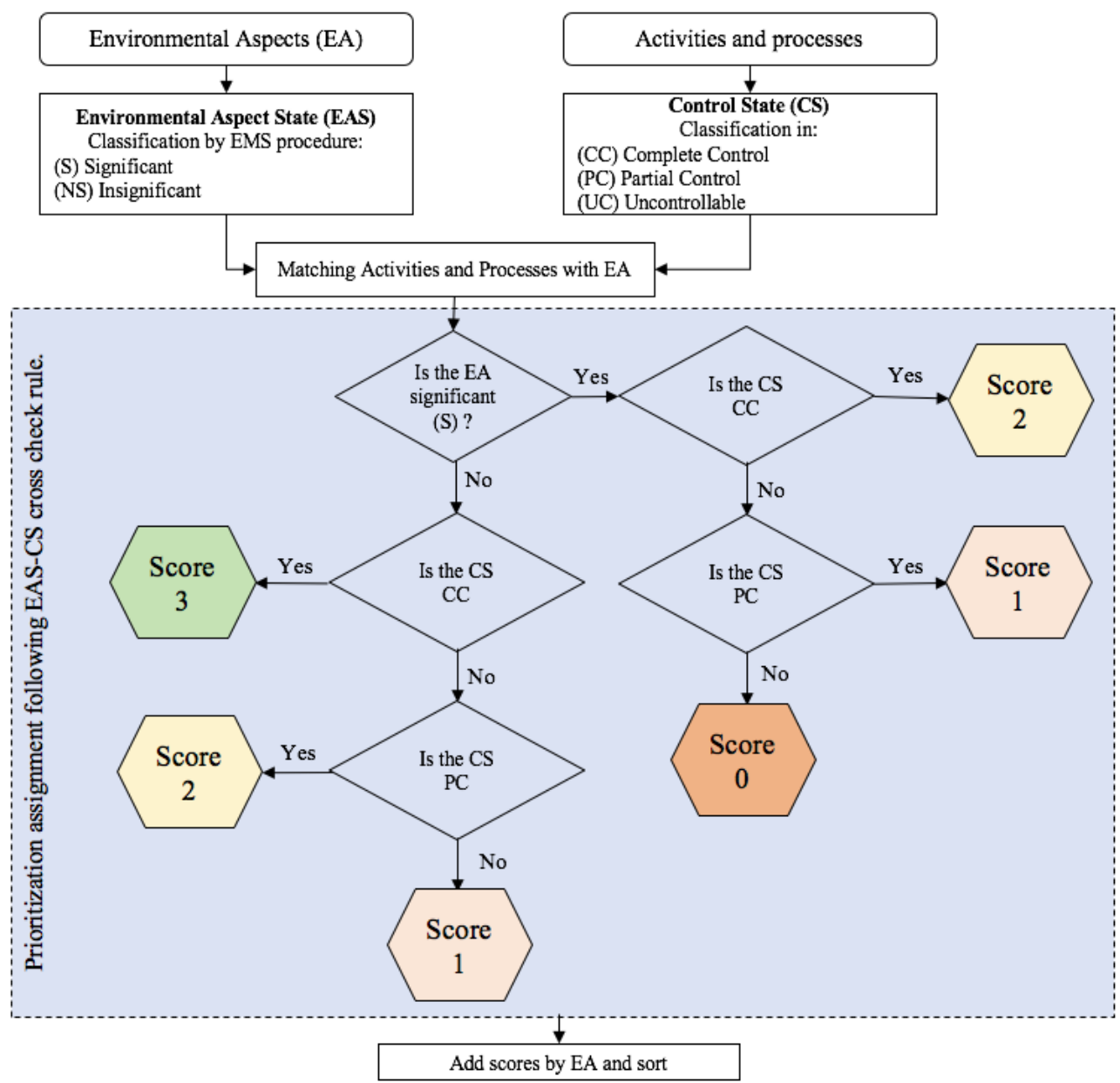

Figure 3. Prioritization procedure cross-score EAS-CS. For more details see Lo-IaconoFerreira et al. (2017) 
Results of each EA are obtained by adding the scores of all activities and processes identified with each EA. As a result, a list of scored EA is obtained. The EA with a higher score deserves more resources (human and economic) to address a more accurate assessment of their impact. Please notices that the prioritization procedure goal is to optimize the use of resources considering, in a first place, those EA where their significance and degree of control allows more improvements with less resources. This procedure does not pretend to classified the EA by its environmental impact as, in this stage, the environmental impact is not yet assessed.

\subsection{Definition of goals}

As is known, EMS certified in ISO or verified in EMAS must define and environmental policy appropriate to the nature, scale and environmental impacts of its activities (International Organization for Standardization, 2004; European commission, 2006). This environmental policy becomes a framework for the definitions of specific goals along with the sorted list of EA developed in the previous step. These goals would serve as seeds in the definition of KPIs process.

This proposal also encourages assessors to consult stakeholders regarding their interest over the environmental performance of the reporting unit. Attending stakeholders' interests significantly improve the chances of addressing successful action planes. Their commitment benefit the outcome of those plans where they are directly involved. Environmental issues usually required the commitment of at least some of the stakeholders, e.g. applying green purchased criteria, managing waste or changing transport mode. However, addressing stakeholders interest requires certain expertise to avoid obstacles in the decision-making process that can lead to paralysis (White, 2015). The procedure to identify stakeholders is not within the scope of this research; several methods are available and discussed by recognized authors as Achterkamp \& Vos (2008) and Bryson (2007), among others. Questionnaire, interviews and behavioral analysis might serve as tools to identify stakeholders' interests. HEIs with EMAS can take advantage of their employee involvement activities to advertise the use of environmental KPIs and benefit from their driving force.

Top-managers are natural stakeholders of the organization and their commitment is extremely important as environmental projects needs to be developed as the equilibrium with the social and economic dimensions might require their full commitment. When top managers of the reporting organization are chosen by competitive elections, environmental needs of stakeholders can be easily identified if environmental issues are included in candidates' program.

Goals can also be defined unilaterally by assessors and validated in further iterations analyzing the commitment of the community with the projects developed to address them. The number of goals are directly proportional with the number of KPIs to define as the aim of KPIs would be to assess the pursue of these goals environmentally related. A conservative number of goals is preferable. Goals can be added on each iteration of the procedure.

\subsection{Definition of KPIs}

The aim of KPIs is to track the performance of the goals established; in this case, environmental goals. They have to be SMART (specific, measurable, achievable, relevant, timely), easy to use, traceable and consistent with the operation of the organization and its policies.

Defining a KPI requires identifying what is going to be measure and how, including the functional or reporting unit to be considered.

When the organization under analysis has an easily-defined outcome (product or service), the functional unit is the concept applied (International Organization for Standardization, 2006). However, for complex organizations as HEIs, the reporting unit can be also useful. The reporting unit is a concept developed for ISO 14072:2014 as a quantified performance expression of the organization to be used as a reference.

Once EA are identified and goals are defined, the definition of environmental KPIs it is mainly a matter of straightforward common sense and know-how of assessors. Notice that the defined KPIs shall be validated in the next step and, as all the methodological procedure is based on a continuous improvement cycle, the expertise of assessors will enrich the review of KPIs in the following iteration. 
A list of environmental indicators applicable to HEIs gathered for the literature review is shown in Annex 1. This list can be used as an inspiration tool to define the most appropriate environmental KPIs considering the EA and the goals previously stated. The list is composed by more than 140 indicators including types A, B, C, D and E and classified under the DPISR framework. Indicators are organized by areas: Air pollution, Biodiversity, Climate change, Energy, Environmental scenarios, Food and beverage, Green economy, Infrastructure, Land use, Materials and resources, Transport, Waste and effluents and Water. A classification of the indicators regarding if they are simple or composite is also included. It has to be considered that additional environmental indicators must be applicable when the organization has specific activities or properties different than the traditional ones, e.g. the management of a forest area with research purposed.

\subsection{Validation method: meta-performance evaluation}

An adaptation of Ramos and Caeiro (2010) meta-performance evaluation method is suggested as validation tool. The validation framework has been originally developed for the assessment of sustainable development indicators but it is flexible enough to be adapted to environmental performance indicators for HEIs. The procedure is carried in two levels:

- Level 1. Performance of KPIs system: planning and methodological approach

- Level 2. Performance of KPIs at the implementation and operation stage

Following Ramos and Caeiro (2010) method, key good-practices factors are suggested in the validation framework for each level to be used as a validation tool for the environmental KPIs defined. In addition, each key good-practice factor required at least one meta-performance evaluation indicator. The complete list of meta-performance evaluation indicators related to key good-practice factors for both levels are described in Annex 2.

The present methodological proposal encourages assessors to address the validation rigorously and strongly advice to consider all the meta-performance evaluation indicators suggested. Once environmental KPIs are defined and validated, they are ready to be integrated in the overall management system of the reporting organization for which they have been defined. If top-managers were not part of the previous process, a detail report shall be presented to them in order to provide insight of their meaning and utility. However, authors of this proposal strongly encourage the consideration of stakeholder's interest and their participation as their commitment might be vital for the success of environmental performance optimization action plans.

The following stages are foreseen as part of regular management operations:

- Targets setting

- Consistency review between indicators and targets

- Policy development

- Definition and implementation of action plans

- Analysis of the degree of compliance of targets

- Reports

Once environmental KPIs are part of the overall management system of the reporting organization, it is expected to consider them in equal basis to any other KPI already integrated. However, their performance should be reported both to the EMS and to assessors in order to track their SMART characteristics and close the continuous improvement cycle.

\subsection{Continuous improvement cycle and reporting}

EMS verified in EMAS has already a continuous improvement procedure as it is required for the verification and its maintenance. The cycle can be easily included in the annual review of the system and verified by the internal audits. International Organization for Standardization (ISO) certified EMS does not ensure this feature; however, it is compatible with the system if there are enough resources available.

The report of the environmental KPIs defined along with their value are highly recommended. The environmental awareness of the community and the commitment of stakeholders can be significantly improved along with the confidence of the society due to a transparent environmental management. 
For those EMS verified in EMAS, KPIs can be easily included as part as the external communications protocol already implemented. As ISO only requires internal communications, an effort has to be made in this direction to improve the benefits of the procedure.

\section{Results: Definition of environmental KPIs for EPSA}

This section presents the results of applying the methodology proposal to define environmental KPIs for a pilot EU of UPV, EPSA.

\subsection{Definition of the reporting organization: EPSA}

UPV is a medium size HEIs located in the south east of Spain and compose by three main campuses in Valencia region, with almost 70 ha of building surface and 13 ha of landscaped area. In 2015, UPV had more than 38000 students and over 8000 staff members. It is, up to now, the biggest HEI (NACE code: 85.42) with an EMS verified in EMAS for the entire university (Code: UPV.MA-INF.RSGA.2015-UPV-01). EMS is managed by the Environmental Office (EO) who takes care of the 211 EU defined.

The decision of applying the methodology to EPSA as a pilot EU of UPV is based on the following:

- Simplicity: HEIs structure are complex and heterogeneous. On the contrary of companies that has a pyramidal structure where the executive committee or president coordinates the different areas compose by several departments; each HEI is one-of-akind. The EU is a well-defined area easy to identify and assess as already defined in the introduction.

- Accessibility: the authors of this paper have extensive knowledge of the operation of EPSA as well as easy access to data related.

EPSA has 2.9 ha of building surface and 1.2 ha of green areas. In 2015 there where 2500 students in this school and 300 staff members.

As a school, EPSA has control over all of the activities that take place under its structure with different degrees of control (see Lo-Iacono-Ferreira et al. (2017) for more details). The activities and processes that takes place in EPSA are listed in table 1 where $\mathrm{CC}$ respond to complete operational control, PC to partial control and UC to uncontrolled. Scopes are identified according to the suggested method described in the methodological proposal.

Table 1. Activities and processes taking place at EPSA

\begin{tabular}{l|c|c} 
Activities and processes & Level of control & Scope \\
\hline Administrative procedures & CC & 1 \\
\hline Air conditioning system & PC & 2 \\
\hline Capital equipment procurement & CC & 3 \\
\hline Employee and students commuting & UC & 3 \\
\hline Heating system & PC & 2 \\
\hline Lighting and lifts system & CC & 2 \\
\hline Mobility with UPV fleet & PC & 1 \\
\hline Outsourcing: Cafeteria & PC & 3 \\
\hline Outsourcing: Cleaning services & PC & 3 \\
\hline Outsourcing: Construction services & PC & 3 \\
\hline Outsourcing: Electric maintenance & PC & 3 \\
\hline Outsourcing: Maintenance of infrastructure & PC & 3 \\
\hline Outsourcing: others & PC & 3 \\
\hline Outsourcing: Security system & PC & 3 \\
\hline Sanitary system & PC & 2 \\
\hline Waste management system & CC & 2 \\
\hline
\end{tabular}

3.1 Identification of relevant environmental aspects

The EO carries the identification and significance assessment of EA of all the EU as part of its EMS routines under EMAS. As a result of the application of the prioritization procedure 
described in the methodological proposal, the scored list of EA for EPSA is shown in table 2 where (S) stands for significant and NS for insignificant.

Table 2. EA of EPSA. List in order by priority top-down (most relevant on top).

\begin{tabular}{|c|c|c|}
\hline Environmental aspects & EAS & Score \\
\hline Electricity consumption & $\mathrm{S}$ & 17 \\
\hline Environmental behavior of external companies ${ }^{(a)}$ & $\mathrm{S}$ & 14 \\
\hline Waste water generation & $\mathrm{S}$ & 11 \\
\hline Paper and cardboard waste generation & $\mathrm{S}$ & 10 \\
\hline Municipal solid waste generation & NS & 10 \\
\hline Emissions due to electricity consumption ${ }^{(b)}$ & NS & 10 \\
\hline Water consumption & $\mathrm{S}$ & 9 \\
\hline Light packaging waste generation & NS & 9 \\
\hline Office supplies consumption ${ }^{(\mathrm{c})}$ & $\mathrm{S}$ & 6 \\
\hline Ink and tonner waste generation & NS & 5 \\
\hline Electronic waste generation & $\mathrm{S}$ & 4 \\
\hline Batteries waste generation & $\mathrm{S}$ & 3 \\
\hline $\mathrm{CD}$ waste generation & $\mathrm{S}$ & 3 \\
\hline Supplies consumption ${ }^{(\mathrm{c})}$ & $\mathrm{S}$ & 3 \\
\hline Movable assets consumption ${ }^{(\mathrm{c})}$ & $\mathrm{S}$ & 3 \\
\hline Technology assets consumption ${ }^{(\mathrm{c})}$ & $\mathrm{S}$ & 3 \\
\hline Automobile procurement ${ }^{(\mathrm{c})}$ & $\mathrm{S}$ & 2 \\
\hline Emission generation due to gasoil consumption ${ }^{(b)}$ & NS & 2 \\
\hline Automobile waste generation & $\mathrm{S}$ & 2 \\
\hline Debris generation & NS & 2 \\
\hline Fossil fuel consumption: natural gas ${ }^{(\mathrm{d})}$ & NS & 2 \\
\hline Emissions due to natural gas consumption ${ }^{(b)}$ & NS & 2 \\
\hline Emissions due to air conditioning, HFC & NS & 1 \\
\hline Oil, fuel and hydrocarbons waste generation & NS & 1 \\
\hline Fossil fuel consumption: gasoil (d) & NS & 1 \\
\hline Noise generation & NS & 0 \\
\hline Mobility of students & NS & 0 \\
\hline
\end{tabular}

Note: (a) It refers to outsourcing. (b) EMS assessed a unified EA for emissions due to energy. It is disaggregated for a better analysis according to the scope of this work. (c) EMS assessed a unified EA for consumption. It is disaggregated for a better analysis according to the scope of this work. (d) EMS assessed a unified EA for fossil fuel consumption. It is disaggregated for a better analysis according to the scope of this work.

It has to be notices that, although some aspects might be considered insignificant from the EO point of view, their score in the prioritization procedure is high (upper third of the table) deserving consideration as it is an aspect on which EPSA has full operational control and might obtain a relevant improvement. On the contrary, other aspects that might be considered relevant (e.g. mobility of students) has a low score as EO has currently no operation control within the boundaries established (EPSA).

\subsection{Goals definition}

The motivation of the procedure is the optimization of the environmental performance of the reporting unit; EPSA. However, in order to be operative in the definition of KPIs, specific goals must be described.

As EMAS requires a public environmental policy for the organizations verified, HEIs as UPV has already this work done. The environmental policy applies to all EU, including the reporting 
organization studied here. The environmental policy of UPV can be consulted on www.upv.es; main commitments are:

- Identify, evaluate and minimize any environmental impact of its activities.

- Comply with environmental legal requirements and other requirements applicable to UPV.

- Promote adequate environmental learning for all students.

- Help improve the environmental performance of UPV community in and out HEI. Considering the environmental policy of UPV and the list of EA defined for EPSA, the following specific goals are proposed (table 3 ):

\begin{tabular}{l|l}
\multirow{4}{*}{ Macro-level goal } & Table 3 Goals proposition for EPSA \\
\hline \multirow{3}{*}{ The conservation of natural resources } & Goal \\
\cline { 2 - 2 } & (G1) Minimize non-renewable energy consumption \\
\cline { 2 - 2 } & (G2) Maximize recycling waste \\
\hline \multirow{3}{*}{ The fight against climate change } & (G) Minimize waste generation \\
\cline { 2 - 2 } & (G5) Minimize GHG emissions from scope 1 \\
\cline { 2 - 2 } & (G6) Minimize GHG emissions from scope 2 \\
\hline
\end{tabular}

With these goals definition, only one EA is not represented directly: noise generation; one of the last of the list and already classified as insignificant for EPSA.

\subsection{KPIs definition}

In this section, one functional and two reporting units are defined. These units are used in the definition of specific KPIs for EPSA. The definition of KPIs is completed with the proposal of 7 environmental KPIs and a bonus hopefully applicable in further iterations.

\subsubsection{Functional and reporting units for EPSA}

The functional unit of a HEI has already been widely discussed (Lo-Iacono-Ferreira et al., 2016c) and several options may be considered from which is chosen, for this study, the build-up area (BUA). For those indicators that requires, due to its nature, a reporting unit, the full-time equivalent (FTE) student and the full-time employee are chosen. The description of each unit is presented below.

BUA refers to the when the physical dimension of the organization and represents a perfect unit of dimension of a traditional HEI (mostly classroom training). According to the international system of units, BUA has been measured in square meters $\left(\mathrm{m}^{2}\right)$ and includes all infrastructures and green areas (classrooms, offices, common facilities, parking areas, gardens, etc.).

The European Commission (2016) defines FTE student as student that study full-time. OECD (2016) integrates the course load and the duration of studies in the unit (Eq. 1). When no information of course load is available, OCDE instructed to consider the simplified definition, 1 FTE equals to a full-time student.

FTE student $=\frac{\text { actual course load }}{\text { normal course load }} \cdot \frac{\text { actual duration of study during reference period }}{\text { normal duration of study during reference period }}$

The number of FTE students is obtained by the relation between enrolled credits in the year of analysis and the average credits of a year of an academic course. At UPV, a full-time student takes 60 ECTS credits a year.

A similar definition can be used for FTE employees if needed comparing the average number of hours worked by an employee to the average number of hours of full-time worker (Eq. 2). In Spain, a full-time job has, in average, 40 hours a week.

FTE employee $=\frac{\text { average hours worked }}{\text { average hours of a full-time worker }}$

Notice that both the functional and the reporting unit defined are not restricted to EPSA and can be used in any HEI. 


\subsubsection{Environmental KPIs proposed for EPSA}

As a result of the analysis of the specific goals defined for EPSA and considering the description of environmental KPIs suggested in annex 1, the following KPIs are proposed:

ENV KPI 1: Ratio of renewable energy consumption over the total energy consumption This indicator measures the renewable energy consumption in MWh, both purchase and own generation, over the total energy consumption in MWh. It is a response indicator according to DPSIR framework and has no units as it is a ratio. It is directly related to goals G1 and G5 as it considers the electric energy consumption purchased and own generated.

It can be easily accessed through direct measurements. Data sources for this indicator may be electric instrumentation and invoices details. The desired value is 1 where all the energy consumed comes from renewable sources.

\section{ENV KPI 2: Ratio of waste recycled over the total waste generated}

This indicator measures the amount of waste recycled over the total waste generated in kilograms. Recycling waste is considered both if it is self-processed or send to a recycling entity. It is a response indicator with no units. It is related with goals G2 and G3.

Weights of wastes can be measured either in the institution before deliver or by the waste manager in which case it requires its collaboration. Although direct measures are preferable, estimation methods can be used for a first approach. As the indicator approaches unity, the percentage of unrecycled waste would gain insignificancy. It has to be considered the influence of local laws when regulating the waste treatment system and that not all waste can be recycled.

ENV KPI 3: GHG emissions of Scope 1 * by BUA

This indicator measures the emissions due to machinery and equipment run with by combustion engines, boilers and use of own fleet (Scope 1). It is a pressure indicator assessed in tons of $\mathrm{CO}_{2} \mathrm{e}$ per $\mathrm{m}^{2}$. It is directly related to goal G4.

The assessment of GHG emissions has to be done based on a standard procedure, e.g., ISO 14064 along with a detailed definition of the scope. It is essential to have a complete inventory of vehicles, combustion engine machinery and boilers owned and installed in the institution along with their technical specifications. Targets can be set annually to help focused efforts in reducing these emissions.

ENV KPI 4: Ratio of sustainable purchases over the total of purchases

This indicator measures the monetary value (U\$S or $€$ ) of purchases of materials and services applying a published or standardized sustainable criteria (e.g. ISO 20400) over the total of purchases made by the HEI. It is a response indicator with no units and directly related to goal G6.

The sources of information for the assessment of this indicator can be newsletter tenders, applications, invoices, etc. Having a centralize accounting system with an electronic register of purchases is desirable. The final goal would be having a rate of one to ensure all purchases are made under sustainable criteria.

\section{ENV KPI 5: Ratio of sustainable tenders over total tenders}

This indicator measures the number of contracts for tenders made with published or standardized sustainable criteria over the total of tenders of HEIs. It is a response indicator with no units and directly related to goal G6.

The sources of information for the assessment are the newsletter tenders and contracts of the tender. As ENV KPI 4, having a value of one would mean that all tenders follow sustainable criteria, therefore, the environment is carefully considered.

\section{ENV KPI 6: GHG emissions from commuting by FTE student}

This indicator measures GHG emissions from commuting in tons or kilograms of $\mathrm{CO}_{2} \mathrm{e}$ per FTE student. It is a pressure indicator related to goal G6.

It is required to know the characteristics of commuting of students. An easy way to introduce this information to the EMS is thorough regular surveys. This information can help in the development of awareness programs and other actions where the HEI can influence public transport services to benefit students. 
ENV KPI 7: GHG emissions from commuting by FTE employee

The assessment of employees commuting is also relevant for goal G6. It is also a pressure indicator as it measures GHG emissions from commuting in tons or kilograms of $\mathrm{CO}_{2} \mathrm{e}$ but related to employees.

The performance of this indicator is different to the previous as the replacement rate is expected to be significantly lower than for student; students stays at HEIs for short periods of time (4 to 6 years in average). The outcomes of programs developed to aware employees of the benefits of an environmentally friendly mobility would stay longer in the institution and would also serve as example for students.

The seven indicators previously described can be measured in a defined time period, normally a year. They are related to, at least, one goal proving to be crucial factors representing a key indicator. They are SMART and consistence with the EMS being easy to include with small adjustments in a robust EMS as the ones verified in EMAS. Having these indicators as part of EMS ensure that they are measurable. They are also easy to use as functional and reporting units are part of the current performance analysis of the institution. Ratios are easy to read and sensible to changes of the reporting organization.

Furthermore, considering that EPSA has initiated a process to adapt its EMS to carry out a LCA (i.e. Organizational Life Cycle Assessment (OLCA)) an additional KPI is proposed. ENV KPI 8 might simplify the set of KPIs be replacing ENV KPI 4, ENV KPI 5, ENV KPI 6 and ENV KPI 7.

\section{ENV KPI 8: GHG emissions of Scope 3 * by FTE student}

This indicator measures the emissions due to tenders, purchasing and commuting both for employees and students (Scope 3). It is a pressure indicator assessed in tons or kilograms of $\mathrm{CO}_{2} \mathrm{e}$ per FTE. It is directly related to goal G6.

The assessment of GHG emissions has to be done based on a standard procedure, e.g., ISO 14072:2014 along with a detailed definition of the scope. The difficulty of this indicators lies in gathering all the information required. For that reason, it is proposed as an indicator when a previous life cycle assessment has been carried and the data network is already stablished. Notice that, if needed for management purposes, ENV KPI indicators from 4 to 7 can be used for a deeper interpretation of the results of this indicator.

\subsection{Assessment of environmental KPIs for EPSA}

The results of assessment of these indicators for EPSA is shown in table 4.

Table 4 ENV KPI results for EPSA, 2015.

\begin{tabular}{l|l|l} 
KPI & Result & Observation \\
\hline ENV KPI 1 & 0.37 & $\begin{array}{l}\text { All the energy consumed by EPSA is registered by } \\
\text { the EMS using the corresponding invoices and } \\
\text { related documentation as data source. Although } \\
\text { there might be small renewable energy generators } \\
\text { installed with research purposes, research activities } \\
\text { are not within the scope of this reporting } \\
\text { organization. }\end{array}$ \\
\hline ENV KPI 2 & 0.43 & $\begin{array}{l}\text { It has to be considered that the weight of non- } \\
\text { recycled waste (municipal solid waste) is estimated } \\
\text { by a procedure developed by EMS. }\end{array}$ \\
\hline ENV KPI 3 & $9.66 \mathrm{~kg} \mathrm{CO}_{2} \mathrm{e}$ per BUA & $\begin{array}{l}\text { The assessment of emissions has been made } \\
\text { following the Spanish environmental ministry } \\
\text { procedure. }\end{array}$ \\
\hline & - & $\begin{array}{l}\text { Although there are good practices guidance for } \\
\text { green procurement available to all members of } \\
\text { UPV, there is no centralized register of } \\
\text { procurement in the system at the time of publishing } \\
\text { this article. This indicator could not be assessed. }\end{array}$ \\
\hline
\end{tabular}




\begin{tabular}{c|l|l}
\hline ENV KPI 5 & 1 & $\begin{array}{l}\text { UPV EMS has implemented a procedure to include } \\
\text { sustainability criteria in every tender. As EPSA is } \\
\text { under UPV general regulation, all EPSA tenders } \\
\text { include sustainability criteria. }\end{array}$ \\
\hline ENV KPI 6 & $0.5 \mathrm{t} \mathrm{CO}_{2} \mathrm{e}$ by person & $\begin{array}{l}\text { These indicators couldn't be assessed as the } \\
\text { information in the current system does not } \\
\text { disaggregate between students and employees. } \\
\text { However, the system did allow a result overall the } \\
\text { community. }\end{array}$ \\
\hline ENV KPI 7 &
\end{tabular}

UPV EMS as it is currently working only allows the assessment of four of the 7 KPIs proposed. Therefore, it has to be highlighted that an EMAS verification, although it is a powerful tool to identify the EA and its crucial factors, does not ensure the assessment of KPI to manage them. ENV KPI 1 can be base lines for new targets regarding energy consumption while ENV KPI 3 can be set as a reference for the efficiency of equipment and vehicles owned by UPV that produce $\mathrm{CO}_{2}$. Regarding ENV KPI 2, an additional effort to be able to have a direct measure of municipal solid waste is needed in order to have a more accurate indicator. ENV KPI 5 has the desirable value, however, there is always place for improvement.

Significant changes are required in order to be able to assess ENV KPI 4. Although the EO is working on green procurement guidance as the need is detected, neither the EMS or the accounting system have a quantitative measure of the green procurement.

ENV KPI 6 and ENV KPI 7 could not be evaluated as described because of lack of information or a lack of quality of the information available. However, estimations could be made for a different reporting unit: members of the community (person). The result cannot be disaggregated by FTE-student and FTE-employee as quality data is not available. Although it is not the desirable result, it might be useful to (a) justify the need of more resources to address the KPIs as proposed and (b) baseline for the immediate actions that top-managers would like to achieved. Yet, the disaggregation is considered essential as the profiles of students and employees are different, therefore, the targets and action plans must be particularized.

\subsection{Validation}

Following the methodological proposal described in annex 2, the validation of each indicator has been carried out. In this section, a summary of the results of the validation process is presented.

Regarding the planning and the methodological approach (level 1) meta-performance evaluation indicators, all the proposed indicators have a positive evaluation except for the regular updating and reporting indicator and the reporting and communication to stakeholders that, although specific actions are planned, they have not yet been executed at the moment of publishing this paper. However, some related environmental information is already part of UPV EMAS annual environmental review, therefore, it is reported and communicated e.g., emission for scope 1. The results of the level 2 meta-performance evaluation indicators related to quality control cannot be considered fully successful. The ratio of indicators assessed with direct measurement is $3 / 4$. Because of the nature of GHG emissions calculation involves certain judgment and estimations, all environmental KPIs related to this output have some degree of uncertainty associates. ENV KPI 3, ENV KPI 6, ENV KPI 7 and ENV KPI 8 have two sources of uncertainty: the input and the conversion factor. ENV KPI 3 presents an uncertainty of $1 \%$. The uncertainty of the other KPIs related to emissions could not be assessed due to a lack of quality data.

The uncertainty of ratios which data sources are measuring instruments is easy to evaluate when technical details are available. Although this information is not available for the year under analysis (2015), the procedure to include it in the system is simple: the EO has to add this information to the registers of emissions for ENV KPI 1 and weight of wastes for ENV KPI 2. These information is expected to be registered for further iterations of the assessment. ENV KPI 4 and ENV KPI 5 are not supposed to have significant uncertainties due to the nature of the indicators. 
The conceptual coherence indicator has an optimal value as well as the methodological approach and data calculation indicator, $0 \%$ and $100 \%$ respectively. The same outcome is obtained when considering logistical requirements and information management. EMAS requirements ensure the description and documentation of any procedure developed by the EMS along with the need of communication the result to the community. Finally, a survey to decision-makers shown that all the environmental KPIs proposed for EPSA are easy to understand.

\section{Conclusions}

HEIs have a high flow of people (students) and significant environmental aspects related to their energy consumption and waste generation but also to the scope 3 of the organization; a dimension difficult to assess. Having KPIs as part of the daily management system would make easy to considered all the impacts coming from third parties as tenders, services and materials purchasing. KPIs can be the operational tool to identify opportunities of improvement and tendencies, review system efficiency, help in the identification of strategic opportunities, assess the risk of non-compliance with legal requirements as well as report and communicate the environmental performance of the organization integrating KPIs in ISO 14031 framework. However, to apply these types of assessments and policies the support of top-managers is needed as resources and structural modifications might be necessary. Other weakness of KPIs is that, as all performance indicators, they can only report on aspects that can be measured. Qualitative information, that may be also relevant for performance assessments, is difficult to express through an indicator. On the contrary, KPIs are $100 \%$ adaptable to the characteristics and needs of the organization, even to particular ones as HEIs.

The proposed procedure for the definition of KPI as the validation method chosen proven to be adequate for a HEIs with an EMS already implemented. However, an EMS verified in EMAS does not ensure the availability and desirable quality of all data required. Several advantages have been identified of having an EMS verified in EMAS:

- The institution has already an environmental policy that helps with the definition of goals.

- The system boundaries of the institution are easy to define as the process and activities are clearly identified.

- The environmental aspects are already identified as its significance.

There is a system that collects data related to the environmental aspects of the institution. Regarding UPV KPIs for EPSA, the following conclusions can be taken:

- The energy policy of UPV can be updated and specific actions might be needed to address a better rate of renewable energy.

- Although there are estimation procedures for some data as municipal solid waste generation allowing the assessment of indicators related, these results need to be interpret with care.

- Tenders are handle on sustainable responsible basis while the evidence of green procurement for products and services is hard to find. Resources are needed in order to have a centralized system that gather more accurate information about purchases.

- By assessing GHG emission indicators (Scope 1 by BUA) decision makers have a base line to set targets and policies for the next period time.

- More resources are needed in order to be able to assessed the required data for 3 of the 7 KPIs proposed.

Improving the data quality will improve, significantly, the accuracy of KPIs which make them more useful and will benefit the decision-maker process so as to improve the environmental performance of HEIs.

A set of KPIs may result in a Complex Performance Indicator. Further research can focus on the integration of defined indicators with economic and social KPIs in order to build a Complex Performance Indicator for HEIs. 


\section{References}

Achterkamp, M. C., \& Vos, J. F. J. (2008). Investigating the use of the stakeholder notion in project management literature, a meta-analysis. International Journal of Project Management, 26:7, 749-757. http://doi.org/10.1016/j.ijproman.2007.10.001

Alam, M., Dupras, J., \& Messier, C. (2016). A framework towards a composite indicator for urban ecosystem services. Ecological Indicators, 60, 38-44.

http://doi.org/10.1016/j.ecolind.2015.05.035

Alonso-Almeida, M. D. M., Marimon, F., Casani, F., \& Rodriguez-Pomeda, J. (2015). Diffusion of sustainability reporting in universities: current situation and future perspectives. Journal of Cleaner Production, 106, 144-154. http://doi.org/10.1016/j.jclepro.2014.02.008

Azma, F. (2010). Qualitative Indicators for the evaluation of universities performance. Procedia - Social and Behavioral Sciences, 2(2), 5408-5411. http://doi.org/10.1016/j.sbspro.2010.03.882 Barnetson, B., \& Cutright, M. (2000). Performance indicators as conceptual technologies. Higher Education, 40, 277-292. http://doi.org/10.1023/a:1004066415147

Bauler, T. (2012). An analytical framework to discuss the usability of (environmental) indicators for policy. Ecological Indicators, 17, 38-45.

http://doi.org/10.1016/j.ecolind.2011.05.013

Bonaccorsi, A., Daraio, C., Lepori, B., \& Slipersæter, S. (2007). Indicators on individual higher education institutions: addressing data problems and comparability issues. Research Evaluation, 16(2), 66-78. http://doi.org/10.3152/095820207X218141

Braulio-Gonzalo, M., Bovea, M. D., \& Ruá, M. J. (2015). Sustainability on the urban scale:

Proposal of a structure of indicators for the Spanish context. Environmental Impact Assessment Review, 53, 16-30. http://doi.org/10.1016/j.eiar.2015.03.002

Braunschweig A. (2014) GHG-balances and LCA: Applying the concept of scopes in organisational LCAs. E2 Management Consulting. Retrieved from http://www.e2mc.com. Accessed 1 July 2016.

Bryson, J.M. (2004) What to do when Stakeholders matter. Stakeholder Identification and Analysis Techniques. Journal Public Management review 6:1 21-53

http://dx.doi.org/10.1080/14719030410001675722

Buonocore, E., Mellino, S., De Angelis, G., Liu, G., \& Ulgiati, S. (2016). Model Life cycle assessment indicators of urban wastewater and sewage sludge treatment. Ecological Indicators. http://doi.org/10.1016/j.ecolind.2016.04.047

Campos, L. M. S., Melo Heinzen, D. A. De, Verdinelli, M. A., \& Augusto Cauchick Miguel, P. (2015). Environmental Performance Indicators: A Study on ISO 14001 Certified Companies. Journal of Cleaner Production, 99, 286-296. http://doi.org/10.1016/j.jclepro.2015.03.019 Disterheft, A., da Silva Caeiro, S. S. F., Ramos, M. R., \& de Miranda Azeiteiro, U. M. (2012). Environmental Management Systems (EMS) implementation processes and practices in European Higher Education Institutions-top-down versus participatory approaches. Journal of Cleaner Production, 31, 80-90. http://dx.doi.org/10.1016/j.jclepro.2012.02.034 Dočekalová, M. P., \& Kocmanová, A. (2016). Composite indicator for measuring corporate sustainability. Ecological Indicators, 61, 612-623. http://doi.org/10.1016/j.ecolind.2015.10.012 Doran, George T. "There's a SMART way to write management's goals and objectives." Management review 70.11 (1981): 35-36.

European Commission (2009) European Commission Regulation (EC) No. 1221/2009 of the European Parliament and of the Council of 25 November 2009 on the voluntary participation by organisations in a Community eco-management and audit scheme (EMAS), repealing Regulation (EC) No. 761/2001 and Commission Decisions 2001/681/EC and 2006/193/EC European Commission (2016) Eurostat Glossary. Retrieved July 1, 2016, from http://ec.europa.eu/eurostat/statistics-explained/index.php/Glossary:Full-time equivalent (FTE) European Environment Agency. (2014). Digest of EEA indicators. Luxembourg. Retrieved July 1, 2016, from http://www.eea.europa.eu/publications/digest-of-eea-indicators-2014 European Environmental Agency. (2016). Indicators. Retrieved July 1, 2016, from http://www.eea.europa.eu/data-and-maps/indicators/ 
Fernández, A., Morales, M., Rodríguez, C., \& Salmerón, A. (2011). A system for relevance analysis of performance indicators in higher education using Bayesian networks. Knowledge and Information Systems, 27(3), 327-344. http://doi.org/10.1007/s10115-010-0297-9

Fiksel, J., Spitzely, D., \& Brunetti, T. (2002). Key Performance Indicators (Vol. Substudy 5). Retrieved July 1, 2016, from http://www.wbcsdcement.org/pdf/battelle/final report5.pdf García-Sánchez, I. M., Almeida, T. A. D. N., \& Camara, R. P. D. B. (2015). A proposal for a Composite Index of Environmental Performance (CIEP) for countries. Ecological Indicators, 48, 171-188. http://doi.org/10.1016/j.ecolind.2014.08.004

Global Reporting Initiative. (2013). G4 Guidelines. Retrieved March 1, 2016, from https://www.globalreporting.org/resourcelibrary/G4-Package.zip

Gustavo De Lima, R., Lins, H. N., Pfitscher, E. D., Garcia, J., Suni, A., Salgueirinho Osório De Andrade Guerra, J. B., \& Caroline Renata Delle, F. (2016). A sustainability evaluation framework for Science and Technology Institutes: An international comparative analysis. Journal of Cleaner Production, 125, 145-158. http://doi.org/10.1016/j.jclepro.2016.03.028 Hancock, L., \& Nuttman, S. (2014). Engaging higher education institutions in the challenge of sustainability: Sustainable transport as a catalyst for action. Journal of Cleaner Production, 62, 62-71. http://doi.org/10.1016/j.jclepro.2013.07.062

Hermann, B. G., Kroeze, C., \& Jawjit, W. (2007). Assessing environmental performance by combining life cycle assessment, multi-criteria analysis and environmental performance indicators. Journal of Cleaner Production, 15(18), 1787-1796.

http://doi.org/10.1016/j.jclepro.2006.04.004

Hourneaux, F., Hrdlicka, H. A., Gomes, C. M., \& Kruglianskas, I. (2014). The use of environmental performance indicators and size effect: A study of industrial companies. Ecological Indicators, 36, 205-212. http://doi.org/10.1016/j.ecolind.2013.07.009

Hsu, A., Johnson, L., \& Lloyd, A. (2013). MEASURING PROGRESS. A Practical Guide from the Developers of the Environmental Performance Indez (EPI). New Haven: Yale Center for Environmental Law \& Policy. Retrieved July 1, 2016, from

http://epi.yale.edu/content/measuring-progress-practical-guide-developers-environmentalperformance-index-epi

International Organization for Standardization (2006) ISO 14044: Environmental Management — Life Cycle Assessment - Requirements and Guidelines. Geneva, Switzerland: International Organization for Standardization.

International Organization for Standardization (2013). Environmental Management Environmental Performance Evaluation - Guidelines. International Organization for Standardization International Organization for Standardization (2014) ISO/TS 14072: Environmental management - Life cycle assessment — Requirements and guidelines for Organizational Life Cycle Assessment. Geneva, Switzerland: International Organization for Standardization.

Kerzner, H. R. Project management metrics, KPIs, and dashboards: a guide to measuring and monitoring project performance (2011) John Wiley \& Sons. doi: http://doi.org/10.1002/9781118086254

Lambrechts, W., \& Van Liedekerke, L. (2014). Using ecological footprint analysis in higher education: Campus operations, policy development and educational purposes. Ecological Indicators, 45, 402-406. http://doi.org/http://dx.doi.org/10.1016/j.ecolind.2014.04.043 Lo-Iacono-Ferreira, V. G., Torregrosa-López, J. I., \& Capuz-Rizo, S. F. (2016c). Use of Life Cycle Assessment methodology in the analysis of Ecological Footprint Assessment results to evaluate the environmental performance of universities. Journal of Cleaner Production, 133. http://doi.org/10.1016/j.jclepro.2016.05.04

Lo-Iacono-Ferreira, V.G., Capuz-Rizo, S.F., Torregrosa-López, J.I. (2016a) Ecological Footprint Assessment of Higher Education applying Life Cycle Assessment framework. Case study: Universitat Politència de València. XX International Congress on Project Management and Engineering. Cartagena. 1423-1432. ISBN: 978-84-617-4180-9

Lo-Iacono-Ferreira, V.G., Torregrosa-López, J.I., Capuz-Rizo, S.F., (2016b) Applicability of global reporting initiative to assess the environmental performance of higher education 
institutions. XX International Congress on Project Management and Engineering. Cartagena. 1433-1444. ISBN: 978-84-617-4180-9

Lo-Iacono-Ferreira, V.G., Torreogrsa-López, J.I., Capuz-Rizo, S.F. (2017) Organizational Life Cycle Assessment: suitability for Higher Education Institutions with Environmental Management System. International Journal of Life Cycle Assessment (accepted - under review). Lozano, R., Ceulemans, K., Alonso-Almeida, M., Huisingh, D., Lozano, F. J., Waas, T., ... Hugé, J. (2014). A review of commitment and implementation of sustainable development in higher education: results from a worldwide survey. Journal of Cleaner Production, 108. http://doi.org/10.1016/j.jclepro.2014.09.048

Lukman, R., Krajnc, D., \& Glavi??, P. (2010). University ranking using research, educational and environmental indicators. Journal of Cleaner Production, 18(7), 619-628.

http://doi.org/10.1016/j.jclepro.2009.09.015

Mazzi, A., Mason, C., Mason, M., \& Scipioni, A. (2012). Is it possible to compare environmental performance indicators reported by public administrations? Results from an Italian survey. Ecological Indicators, 23, 653-659. http://doi.org/10.1016/j.ecolind.2012.05.006 Moldan, B., Sková, S. J., \& Charles, T. s H. (2012). How to understand and measure environmental sustainability: Indicators and targets. Ecological Indicators, 17, 4-13. http://doi.org/10.1016/j.ecolind.2011.04.033

Organization for Economic Cooperation and Development. (2008). Key environmental indicators. Paris. Retrieved July 1, 2016, from https://www.oecd.org/env/indicators-modellingoutlooks/37551205.pdf

Organization for Economic Cooperation and Development. (2014). Green Growth Indicators 2014, 147. http://doi.org/10.1787/9789264202030-en

Organization for Economic Cooperation and Development. (2015). Environment at a Glance 2000: OECD Indicators. OECD Publishing. http://doi.org/10.1787/eag-2013-en

Organization for Economic Cooperation and Development. (2016). Glossary of Statistical

Terms. Retrieved July 1, 2016, from http://stats.oecd.org/glossary/detail.asp?ID=5369

Olszak, E. (2012). Composite indicators for a sustainable campus - Design rationale and methodology: The case of the Catholic Institute of Lille. Ecological Indicators, 23, 573-577. http://doi.org/10.1016/j.ecolind.2012.05.021

Perotto, E., Canziani, R., Marchesi, R., \& Butelli, P. (2008). Environmental performance, indicators and measurement uncertainty in EMS context: a case study. Journal of Cleaner Production, 16(4), 517-530. http://doi.org/10.1016/j.jclepro.2007.01.004

Ramos, T. B., \& Caeiro, S. (2010). Meta-performance evaluation of sustainability indicators. Ecological Indicators, 10(2), 157-166. http://doi.org/10.1016/j.ecolind.2009.04.008

Serdar, A. M. (2010). Performance management and key performance indicators for higher education institutions in Serbia. Perspectives of Innovations, Economics and Business, 6(3), 116-119. http://dx.doi.org/10.15208/pieb.2010.95

Smeets, E., \& Weterings, R. (1999). Environmental indicators: Typology and overview. Copenhagen. Retrieved July 1, 2016, from http://www.eea.europa.eu/publications/TEC25 The Association for the Advancement of Sustainability in Higher Education. (2016). stars Technical Manual. Version 2.1. Retrieved July 1, 2016, from http://www.aashe.org/files/documents/STARS/stars_2.1_technical_manual__administrative_update_one.pdf

Torregrosa-López, Juan Ignacio; Lo-Iacono-Ferreira, Vanesa; Martí-Barranco, Cristina, BellverNavarro, C.-G. (2016). The strengths of EMAS as an environmental management system for European university campuses Cristina Martí-Barranco and. International Journal of Environment and Sustainable Development, 15(1), 89-106. http://doi.org/http://dx.doi.org/10.1504/IJESD.2016.073339 United Nations Environment Programme (UNEP). (2012). Key environmental indicators. Retrieved July 1, 2016, from http://www.unep.org/yearbook/2012/pdfs/UYB 2012 CH 4.pdf United Nations Statistics Division (UNSD). (2016). Environmental indicators. Retrieved July 1, 2016, from http://unstats.un.org/unsd/environment/qindicators.htm 
Waheed, B., Khan, F. I., \& Veitch, B. (2011). Developing a quantitative tool for sustainability assessment of HEIs. International Journal of Sustainability in Higher Education, 12(4), 355368. http://doi.org/10.1108/14676371111168278

Walton, S. V., \& Galea, C. E. (2006). Some considerations for applying business sustainability practices to campus environmental challenges. International Journal of Sustainability in Higher Education, 6(2), 147-160. http://doi.org/http://dx.doi.org/10.1108/1467637051058986

White, J. (2015) How much attention to Stakeholders interests? A practitioner's view of the need to take account of stakeholder interests. Global Policy 6:4. 501-503.doi: 10.1111/17585899.12254

Wild, C., Jessen, C., Bednarz, V. N., Rix, L., \& Teichberg, M. (2015). Environmental Indicators. (R. H. Armon \& O. Hänninen, Eds.). Springer. http://doi.org/10.1007/978-94-0179499-2

WRI and WBCSD (2011) Corporate Value Chain (Scope 3) Accounting and Reporting Standard - Supplement to the GHG Protocol Corporate Accounting and Reporting Standard. World Resources Institute and World Business Council for Sustainable Development. Retrieved from http://www.ghgprotocol.org/files/ghgp/public/Corporate-Value-Chain- AccountingReporing-Standard_041613.pdf. Accessed 1 June 2016.

Wright, T. S. A., \& Wilton, H. (2012). Facilities management directors' conceptualizations of sustainability in higher education. Journal of Cleaner Production, 31, 118-125.

http://doi.org/10.1016/j.jclepro.2012.02.030

Zaman, A. U. (2014). Identification of key assessment indicators of the zero waste management systems. Ecological Indicators, 36, 682-693. http://doi.org/10.1016/j.ecolind.2013.09.024 


\section{Annex 1}

The development of this work includes a deep analysis of all the environmental indicators published or included in the main references related. As a result, a recompilation of those environmental indicators applicable to HEIs has been carried along with the classification of each indicator by DPSIR framework and ABCDE typology.

Results are presented in this annex structured in tables by environmental areas. Observations are included when considered appropriate. Further information can be found in the references related. The environmental areas defined are:

- Air pollution (Table 6)

- Biodiversity (Table 7)

- Climate (Table 8)

- Energy (Table 9)

- Environmental scenarios (Table 10)

- Food and beverage (Table 11)

- Green economy (Table 12)

- Infrastructure (Table 13)

- Materials and resources (Table 14)

- Mobility (Table 15)

- Waste and effluents (Table 16)

- Water (Table 17)

The applicability criteria have been carried considering the activities and processes of a medium size institution with a wide range of studying programs. Indicators regarding specific activities that are not of general development (e.g. management of forest) are not included. In those cases, it is suggested to consult specific literature.

Abbreviations and acronyms in tables

AASHE: Association for the Advancement of Sustainability in Higher Education

C: Composite indicator

$\mathrm{CO} 2 \mathrm{e}$ : carbon dioxide equivalent

EEA: European Environmental Agency

FU: Functional Unit

GHG: Greenhouse gases

GRI: Global Reporting Initiative

ODS: ozone-depleting substances

OP: operations. Refers to AASHE naming for its operational indicators

OECD: Organization for Economic CO-operation and Development

$\mathrm{S}$ : Simple indicator

UNSD: United Nations Statistics Division 
Table 5 Air pollution indicators applicable to HEIs.

\begin{tabular}{|c|c|c|c|c|c|c|}
\hline Indicator & Unit & DPSIR & ABCDE & S or C & Reference & Observations \\
\hline $\begin{array}{l}\text { Emission of acidifying } \\
\text { substances }\end{array}$ & tons & $\mathrm{P}$ & $\mathrm{B}$ & $\mathrm{S}$ & (EEA, 2014) & \\
\hline Emissions of ozone precursors & tons & $\mathrm{P}$ & $\mathrm{B}$ & $\mathrm{S}$ & (EEA, 2014) & \\
\hline $\begin{array}{l}\text { Emissions of ozone particulate } \\
\text { matter and secondary particulate } \\
\text { matter precursors }\end{array}$ & tons & $\mathrm{P}$ & $\mathrm{B}$ & S & (EEA, 2014) & \\
\hline $\begin{array}{l}\text { Exceedance of air quality limit } \\
\text { values in urban areas }\end{array}$ & $\%$ & S & A & $\mathrm{S}$ & (EEA, 2014) & \\
\hline Outdoor air quality & Points & S & A & $\mathrm{C}$ & (AASHE, 2016) & $\begin{array}{l}\text { AASHE index by points that accounts for having policies or } \\
\text { guidelines to improve outdoor air quality and inventory of } \\
\text { significant air emissions from stationary campus sources. }\end{array}$ \\
\hline Particulates PM10 emissions & tons & $\mathrm{P}$ & B & $\mathrm{S}$ & (OCDE, 2014) & \\
\hline Particulates PM2.5 emissions & tons & $\mathrm{P}$ & $\mathrm{B}$ & $\mathrm{S}$ & (OCDE, 2014) & \\
\hline $\begin{array}{l}\text { Exposure of ecosystems to } \\
\text { acidification, eutrophication and } \\
\text { ozone }\end{array}$ & & $\mathrm{S}$ & $\mathrm{B}$ & & $($ EEA, 2014) & \\
\hline
\end{tabular}


Table 6 Biodiversity indicators applicable to HEIs.

\begin{tabular}{l|l|l|l|l|l|l} 
Indicator & Unit & DPSIR & ABCDE & $\begin{array}{l}\text { S or } \\
\text { C }\end{array}$ & Reference & Observations \\
\hline Ecological Footprint & & P & A & C & $\begin{array}{l}\text { (EEA, 2014; Singh et al., } \\
\text { 2012) }\end{array}$ & Composite indicator \\
\hline $\begin{array}{l}\text { Area protected to } \\
\text { maintain biological } \\
\text { diversity to surface area }\end{array}$ & $\begin{array}{l}\text { per cent of } \\
\text { total territorial } \\
\text { area } \\
\text { ha }\end{array}$ & D & A & S & $\begin{array}{l}\text { (UNEP, 2012; UNSD, } \\
\text { 2016; GRI, 2013) }\end{array}$ & $\begin{array}{l}\text { GRI propose this indicator as to be measured by } \\
\text { operational sites owned, leased, managed in, or } \\
\text { adjacent to, protected areas and areas of high } \\
\text { biodiversity value outside protected areas. }\end{array}$ \\
\hline
\end{tabular}


Table 7 Climate indicators applicable to HEIs.

\begin{tabular}{|c|c|c|c|c|c|c|}
\hline Indicator & Unit & DPSIR & ABCDE & S or $\mathrm{C}$ & Reference & Observations \\
\hline Irrigation water requirement & & I & A & $\mathrm{S}$ & (EEA, 2014) & \\
\hline $\begin{array}{l}\text { Production and consumption } \\
\text { of ozone depleting } \\
\text { substances }\end{array}$ & & $\mathrm{D}$ & $\mathrm{D}$ & $S$ & (EEA, 2014) & \\
\hline GHG emission trends & & $\mathrm{P}$ & $\mathrm{B}$ & $S$ & $(\mathrm{EEA}, 2014)$ & \\
\hline GHG emissions intensity & $\begin{array}{l}\text { tons CO2e } \\
\text { per FU }\end{array}$ & $\mathrm{I}$ & B & $S$ & (GRI, 2013) & \\
\hline GHG emissions & Points & $\mathrm{P}$ & B & $\mathrm{C}$ & (AASHE, 2016) & $\begin{array}{l}\text { AASHE index that recognizes HEIs that } \\
\text { assess GHG emissions for Scope } 1 \text {, Scope } 2 \\
\text { and Scope } 3 \text { (optative). }\end{array}$ \\
\hline GHG emissions & $\begin{array}{l}\text { billion tons } \\
\text { of CO2e } \\
\text { billion tons } \\
\text { CO2e per } \\
\text { capita }\end{array}$ & $\mathrm{P}$ & B & $S$ & $\begin{array}{l}\text { (UNEP, 2012; OECD, 2014, } \\
\text { 2015; UNSD, 2016; } \\
\text { Docekalova, 2016; GRI, } \\
\text { 2013) }\end{array}$ & $\begin{array}{l}\text { UNSD proposed this indicator as a net value } \\
\text { and disaggregated by areas (agriculture, } \\
\text { energy, industry, transport and waste). } \\
\text { GRI propose this indicator disaggregated by } \\
\text { scope. }\end{array}$ \\
\hline HFCs emissions - all gases & gig grams & $\mathrm{P}$ & B & $S$ & (UNEP, 2012; OCDE, 2014) & $\begin{array}{l}\text { OCDE proposed this indicator as net } \\
\text { emission and disaggregated by sector } \\
\text { (industry and household). }\end{array}$ \\
\hline CH4emissions & tons & $\mathrm{P}$ & B & S & $\begin{array}{l}\text { (OCDE, 2014; UNSD, } \\
\text { 2016) }\end{array}$ & $\begin{array}{l}\text { This indicator is proposed both as net } \\
\text { emission and disaggregated by sector } \\
\text { (industry and household). }\end{array}$ \\
\hline $\mathrm{N} 2 \mathrm{O}$ emissions & tons & $\mathrm{P}$ & B & $S$ & $\begin{array}{l}\text { (OCDE, 2014; UNSD, } \\
\text { 2016) }\end{array}$ & \\
\hline Perfluorocarbons emissions & tons & $\mathrm{P}$ & B & $S$ & $\begin{array}{l}\text { (OCDE, 2014; UNSD, } \\
\text { 2016) }\end{array}$ & $\begin{array}{l}\text { This indicator is proposed both as net } \\
\text { emission and disaggregated by sector } \\
\text { (industry and household). }\end{array}$ \\
\hline $\begin{array}{l}\text { Sulphur hexafluoride } \\
\text { emissions }\end{array}$ & tons & $\mathrm{P}$ & B & $\mathrm{S}$ & (OCDE, 2014) & $\begin{array}{l}\text { This indicator is proposed both as net } \\
\text { emission and disaggregated by sector } \\
\text { (industry and household). }\end{array}$ \\
\hline
\end{tabular}




\begin{tabular}{l|l|l|l|l|l|l} 
Indicator & Unit & DPSIR & ABCDE & S or C & Reference & Observations \\
\hline $\begin{array}{l}\text { Nitrogen trifluoride } \\
\text { emissions }\end{array}$ & tons & P & B & S & $\begin{array}{l}\text { This indicator is proposed both as net } \\
\text { emission and disaggregated by sector } \\
\text { (industry and household). }\end{array}$ \\
\hline CO2 emissions per capita & tons & P & B & S & $\begin{array}{l}\text { (UNEP, 2012; OECD, 2014, } \\
\text { 2015; García-Sánchez, } \\
\text { Olszak, 2012) }\end{array}$ \\
\hline $\begin{array}{l}\text { Process to greenhouse gas } \\
\text { emissions targets }\end{array}$ & & P & A & C & (EEA, 2014) \\
\hline
\end{tabular}

Table 8 Energy indicators applicable to HEIs

\begin{tabular}{|c|c|c|c|c|c|c|}
\hline Indicator & Unit & DPSIR & ABCDE & $\mathbf{S}$ or $\mathbf{C}$ & Reference & Observations \\
\hline Energy efficiency & & $\mathrm{P}$ & $\mathrm{A}$ & $\mathrm{S}$ & (EEA, 2014; Docekalova, 2016) & \\
\hline Energy intensity & $\mathrm{MWh} / \mathrm{FU}$ & $\mathrm{P}$ & $\mathrm{B}$ & $\mathrm{S}$ & (GRI, 2013) & \\
\hline Energy consumption & MWh & $\mathrm{D}$ & A & $\mathrm{S}$ & $\begin{array}{l}\text { (EEA, 2014; UNSD, 2016; García- } \\
\text { Sánchez, 2015; Olszak, 2012; GRI, } \\
\text { 2013) }\end{array}$ & $\begin{array}{l}\text { EEA propose this indicator as a net } \\
\text { value and disaggregated by sectors. }\end{array}$ \\
\hline $\begin{array}{l}\text { Energy consumption outside } \\
\text { the organization }\end{array}$ & MWh & $\mathrm{P}$ & A & $\mathrm{S}$ & (GRI, 2013) & \\
\hline $\begin{array}{l}\text { Renewable energy } \\
\text { consumption }\end{array}$ & MWh & $\mathrm{R}$ & B & $\mathrm{S}$ & (EEA, 2014; Olszak, 2012) & \\
\hline Progress of energy efficiency & & $\mathrm{R}$ & $\mathrm{C}$ & $\mathrm{S}$ & $(\mathrm{EEA}, 2014)$ & \\
\hline Building energy consumption & $\mathrm{kW} / \mathrm{m} 2$ & $\mathrm{D}$ & $\mathrm{C}$ & $\mathrm{S}$ & Own development & $\begin{array}{l}\text { Reduction of energy usage by area } \\
\text { referred to a baseline year. }\end{array}$ \\
\hline $\begin{array}{l}\text { Reduction of energy } \\
\text { consumption }\end{array}$ & $\%$ & $\mathrm{D}$ & $\mathrm{D}$ & $\mathrm{S}$ & (GRI, 2013) & \\
\hline Clean and Renewable Energy & Points & $\mathrm{R}$ & A & $\mathrm{S}$ & (AASHE, 2016) & $\begin{array}{l}\text { AASHE index (OP 6) that recognizes } \\
\text { HEIs that support the development and } \\
\text { use of energy from clean and renewable } \\
\text { sources. }\end{array}$ \\
\hline
\end{tabular}


Table 9 Environmental scenario indicators applicable to HEIs.

\begin{tabular}{|c|c|c|c|c|c|c|}
\hline Indicator & Unit & DPSIR & ABCDE & S or $\mathbf{C}$ & Reference & Observations \\
\hline $\begin{array}{l}\text { Environmentally related } \\
\text { Research and Development } \\
\text { projects }\end{array}$ & & $\mathrm{R}$ & A & S & (OCDE, 2014, 2015) & \\
\hline $\begin{array}{l}\text { Environmental grievance } \\
\text { mechanisms }\end{array}$ & & $\mathrm{R}$ & $\mathrm{D}$ & S & (GRI, 2013) & $\begin{array}{l}\text { Number of grievances about environmental } \\
\text { impacts filed, addressed, and resolved through } \\
\text { formal grievance mechanisms }\end{array}$ \\
\hline Total population & & $\mathrm{D}$ & A & $\mathrm{S}$ & $\begin{array}{l}\text { (EEA, 2014; OCDE, 2014; } \\
\text { García-Sánchez, 2015) }\end{array}$ & \\
\hline Investments & U\$s or $€$ & $\mathrm{R}$ & $\mathrm{D}$ & $\mathrm{S}$ & $\begin{array}{l}\text { (OCDE, 2014; Docekalova, } \\
\text { 2016; GRI, 2013) }\end{array}$ & $\begin{array}{l}\text { This indicator is proposed as net valua and also } \\
\text { dissagregated by area and by industrial sector. }\end{array}$ \\
\hline Expenditures & U\$s or $€$ & $\mathrm{R}$ & $\mathrm{D}$ & $\mathrm{S}$ & $\begin{array}{l}\text { (Docekalova, 2016; GRI, } \\
\text { 2013) }\end{array}$ & \\
\hline Environmental fines & U\$s or $€$ & $\mathrm{R}$ & $\mathrm{D}$ & S & (GRI, 2013) & $\begin{array}{l}\text { GRI discribe this indicator in detail as the value } \\
\text { of significant fines and total number of non- } \\
\text { monetary sanctions for non-compliance with } \\
\text { environmental laws and regulations. }\end{array}$ \\
\hline $\begin{array}{l}\text { Compliance with legal } \\
\text { requirements }\end{array}$ & $\%$ & $\mathrm{R}$ & $\mathrm{C}$ & $\mathrm{S}$ & (Docekalova, 2016) & \\
\hline $\begin{array}{l}\text { Description of significant } \\
\text { impacts of activities, products, } \\
\text { and services on biodiversity in } \\
\text { protected areas and areas of } \\
\text { high biodiversity value outside } \\
\text { protected areas }\end{array}$ & & $\mathrm{S}$ & A & $\mathrm{C}$ & & \\
\hline
\end{tabular}


Table 10 Food and beverage indicators applicable to HEIs.

\begin{tabular}{l|l|l|l|l|l|l} 
Indicator & Unit & DPSIR & ABCDE & S or C & Reference & Observations \\
\hline $\begin{array}{l}\text { Food and } \\
\text { beverage } \\
\text { purchasing }\end{array}$ & Points & D & D & C & $\begin{array}{l}\text { (AASHE, } \\
2016)\end{array}$ & $\begin{array}{l}\text { AASHE index (OP 7) that recognizes HEIs that support environmentally and } \\
\text { socially responsible purchase of food and beverage. }\end{array}$ \\
\hline $\begin{array}{l}\text { Sustainable } \\
\text { Dining }\end{array}$ & Points & R & D & C & $\begin{array}{l}\text { (AASHE, } \\
\text { 2016) }\end{array}$ & $\begin{array}{l}\text { AASHE index (OP 8) that recognizes HEIs that offer low impact dining } \\
\text { options and educates its customers about sustainable practices in dining. }\end{array}$ \\
\hline
\end{tabular}

Table 11 Green economy indicators applicable to HEIs.

\begin{tabular}{|c|c|c|c|c|c|c|}
\hline Indicator & Unit & DPSIR & ABCDE & $\mathbf{S}$ or $\mathbf{C}$ & Reference & Observations \\
\hline $\begin{array}{l}\text { Number of organizations with } \\
\text { registered EMS according to } \\
\text { EMAS and ISO } 14001\end{array}$ & $\begin{array}{l}\text { number of } \\
\text { organizations }\end{array}$ & $\mathrm{R}$ & A & $\mathrm{S}$ & $\begin{array}{l}(\text { EEA, } \\
2014)\end{array}$ & \\
\hline $\begin{array}{l}\text { Number of certifications of the } \\
\text { ISO } 14001 \text { standard }\end{array}$ & $\begin{array}{l}\text { number of } \\
\text { certifications }\end{array}$ & $\mathrm{R}$ & A & $\mathrm{S}$ & $\begin{array}{l}\text { (UNEP, } \\
2012)\end{array}$ & \\
\hline $\begin{array}{l}\text { Technology development } \\
\text { environmentally related }\end{array}$ & $\begin{array}{l}\text { number of } \\
\text { patents }\end{array}$ & $\mathrm{R}$ & A & $\mathrm{S}$ & $\begin{array}{l}\text { (OCDE, } \\
2014)\end{array}$ & $\begin{array}{l}\text { This indicator is proposed as a net value and } \\
\text { disaggregated by area related (environmental } \\
\text { management, water, climate change mitigation) and } \\
\text { more specific subareas for a deeper analysis. The } \\
\text { identification of international collaboration for each } \\
\text { subarea is also suggested. The list of sub-indicators } \\
\text { proposed it extends to more than } 150 \text { indicators. This } \\
\text { number doubles when the diffusion coverage of each } \\
\text { indicator is assessed as a new indicator. }\end{array}$ \\
\hline $\begin{array}{l}\text { New suppliers that were screened } \\
\text { using environmental criteria }\end{array}$ & $\%$ & $\mathrm{R}$ & $\mathrm{D}$ & $\mathrm{S}$ & (GRI, 2013) & \\
\hline $\begin{array}{l}\text { Significant actual and potential } \\
\text { negative environmental impacts in } \\
\text { the supply chain and actions taken }\end{array}$ & & $\mathrm{R}$ & $\mathrm{D}$ & $\mathrm{C}$ & (GRI, 2013) & \\
\hline
\end{tabular}


Table 12 Infrastructure indicators applicable to HEIs.

\begin{tabular}{|c|c|c|c|c|c|c|}
\hline Indicator & Unit & DPSIR & ABCDE & S or C & Reference & Observations \\
\hline $\begin{array}{l}\text { Building operations } \\
\text { and maintenance }\end{array}$ & Points & $\mathrm{R}$ & A & $\mathrm{C}$ & $\begin{array}{l}\text { (AASHE, } \\
\text { 2016) }\end{array}$ & $\begin{array}{l}\text { AASHE index (OP } 3 \text { ) relates to the area and type of certification or under } \\
\text { published operation and maintenance guidelines and policies of all } \\
\text { buildings }\end{array}$ \\
\hline $\begin{array}{l}\text { Building operations } \\
\text { and maintenance }\end{array}$ & - & $\mathrm{R}$ & A & $\mathrm{S}$ & $\begin{array}{l}\text { Own } \\
\text { development } \\
\text { based on } \\
\text { AASHE } \\
\text { (2016) OP } 3\end{array}$ & $\begin{array}{l}\text { No. of buildings certified under green building rating system or under } \\
\text { any published operation and maintenance guidelines and policies. }\end{array}$ \\
\hline $\begin{array}{l}\text { Buildings with } \\
\text { HEQ certification }\end{array}$ & $\%$ & $\mathrm{R}$ & A & $\mathrm{S}$ & $\begin{array}{l}\text { (Olszak } \\
\text { 2012) }\end{array}$ & \\
\hline $\begin{array}{l}\text { Building operations } \\
\text { and maintenance }\end{array}$ & $\mathrm{m} 2$ & $\mathrm{R}$ & A & S & $\begin{array}{l}\text { Own } \\
\text { development } \\
\text { based on } \\
\text { AASHE } \\
\text { (2016) OP } 3\end{array}$ & $\begin{array}{l}\text { Area of buildings certified under green building rating system or under } \\
\text { any published operation and maintenance guidelines and policies. }\end{array}$ \\
\hline $\begin{array}{l}\text { Building design } \\
\text { and construction }\end{array}$ & Points & $\mathrm{R}$ & A & $\mathrm{C}$ & $\begin{array}{l}\text { (AASHE, } \\
2016)\end{array}$ & $\begin{array}{l}\text { AASHE index (OP 4) relates to the surface and type of certification of } \\
\text { buildings constructed or major renovated in the last five years. }\end{array}$ \\
\hline $\begin{array}{l}\text { Building design } \\
\text { and construction }\end{array}$ & - & $\mathrm{R}$ & A & $S$ & $\begin{array}{l}\text { Own } \\
\text { development } \\
\text { based on } \\
\text { AASHE } \\
\text { (2016) OP } 4\end{array}$ & $\begin{array}{l}\text { No. of buildings certified constructed or major renovated in the last five } \\
\text { years with a green building certification or developed under published } \\
\text { green building guidelines and policies. }\end{array}$ \\
\hline $\begin{array}{l}\text { Building design } \\
\text { and construction }\end{array}$ & $\mathrm{m} 2$ & $\mathrm{R}$ & A & $S$ & $\begin{array}{l}\text { Own } \\
\text { development } \\
\text { based on } \\
\text { AASHE } \\
\text { (2016) OP } 4\end{array}$ & $\begin{array}{l}\text { Area of buildings certified constructed or major renovated in the last five } \\
\text { years with a green building certification or developed under published } \\
\text { green building guidelines and policies. }\end{array}$ \\
\hline $\begin{array}{l}\text { Building energy } \\
\text { consumption }\end{array}$ & Points & $\mathrm{D}$ & A & $\mathrm{C}$ & $\begin{array}{l}\text { (AASHE, } \\
2016)\end{array}$ & $\begin{array}{l}\text { AASHE index (OP 5) that recognizes institutions that have reduce their } \\
\text { building energy usage. }\end{array}$ \\
\hline
\end{tabular}


Table 13 Land use indicators applicable to HEIs.

\begin{tabular}{|c|c|c|c|c|c|c|}
\hline Indicator & Unit & DPSIR & $\mathrm{ABCDE}$ & $\mathrm{S}$ or $\mathrm{C}$ & Reference & Observations \\
\hline Land take & ha & $\mathrm{P}$ & A & $\mathrm{S}$ & $\begin{array}{l}\text { (EEA, 2014, OCDE, } \\
\text { 2014; Docekalova, } \\
\text { 2016) }\end{array}$ & \\
\hline Green open space & $\%$ & $\mathrm{~S}$ & $\mathrm{~A}$ & $\mathrm{~S}$ & (Olszak, 2012) & \\
\hline Landscape Management & Points & $\mathrm{R}$ & $\mathrm{D}$ & $\mathrm{C}$ & (AASHE, 2016) & $\begin{array}{l}\text { AASHE index (OP 9) that recognize HEIs that } \\
\text { manage land take to meet human needs and } \\
\text { maintain healthy ecosystems through Integrated } \\
\text { Pest Management or Organic Land Care Standards. }\end{array}$ \\
\hline $\begin{array}{l}\text { Arable land and permanent } \\
\text { crops }\end{array}$ & ha & $\mathrm{D}$ & A & $\mathrm{S}$ & $\begin{array}{l}\text { (OCDE, 2014; UNSD, } \\
2016)\end{array}$ & \\
\hline $\begin{array}{l}\text { Permanent meadows and } \\
\text { pastures }\end{array}$ & ha & $\mathrm{D}$ & A & $S$ & $\begin{array}{l}\text { (OCDE, 2014; UNSD, } \\
\text { 2016) }\end{array}$ & \\
\hline Forest & ha & $\mathrm{D}$ & A & $\mathrm{S}$ & $\begin{array}{l}\text { (OCDE, 2014; UNSD, } \\
2016)\end{array}$ & \\
\hline Other areas & ha & $\mathrm{D}$ & A & $\mathrm{S}$ & (OCDE, 2014) & \\
\hline $\begin{array}{l}\text { Arable and cropland, \% total } \\
\text { land area }\end{array}$ & $\%$ & $\mathrm{D}$ & A & $\mathrm{S}$ & (OCDE, 2014) & \\
\hline $\begin{array}{l}\text { Pastures and meadows, \% total } \\
\text { land area }\end{array}$ & $\%$ & $\mathrm{D}$ & A & $\mathrm{S}$ & (OCDE, 2014) & \\
\hline Forest, $\%$ total land area & $\%$ & $\mathrm{D}$ & A & $\mathrm{S}$ & $\begin{array}{l}\text { (OCDE, 2014; Moldan } \\
\text { et al., 2012) }\end{array}$ & \\
\hline Other land, \% total land area & $\%$ & $\mathrm{D}$ & A & $S$ & (OCDE, 2014) & \\
\hline
\end{tabular}


Table 14 Materials and resources

\begin{tabular}{|c|c|c|c|c|c|c|}
\hline Indicator & Unit & DPSIR & ABCDE & $\begin{array}{l}\text { S } \\
\text { or } \\
\text { C }\end{array}$ & Reference & Observations \\
\hline $\begin{array}{l}\text { Materials and raw } \\
\text { materials } \\
\text { consumption }\end{array}$ & $\begin{array}{l}\text { tons or } \\
\text { m3 }\end{array}$ & $\mathrm{D}$ & A & $\mathrm{S}$ & $\begin{array}{l}\text { (Docekalova, } \\
\text { 2016; GRI, } \\
\text { 2013) }\end{array}$ & \\
\hline $\begin{array}{l}\text { Percentage of } \\
\text { materials used } \\
\text { that are recycled } \\
\text { input materials }\end{array}$ & $\%$ & $\mathrm{R}$ & $\mathrm{C}$ & $\mathrm{S}$ & (GRI, 2013) & \\
\hline $\begin{array}{l}\text { Paper } \\
\text { consumption }\end{array}$ & tons & $\mathrm{D}$ & A & $\mathrm{S}$ & $\begin{array}{l}\text { (Olszak, } \\
\text { 2012) }\end{array}$ & \\
\hline $\begin{array}{l}\text { Sustainable } \\
\text { Procurement }\end{array}$ & Points & $\mathrm{D}$ & $\mathrm{D}$ & $\mathrm{C}$ & $\begin{array}{l}\text { (AASHE, } \\
2016)\end{array}$ & $\begin{array}{l}\text { AASHE index (OP 11) that recognizes HEIs that apply sustainability criteria } \\
\text { (published and/or standardized) when making procurement decisions, e.g. LIFE } \\
\text { CYCLE COST ANALYSIS) }\end{array}$ \\
\hline $\begin{array}{l}\text { Environmentally } \\
\text { friendly products } \\
\text { used }\end{array}$ & $\%$ & $\mathrm{R}$ & $\mathrm{D}$ & $\mathrm{S}$ & $\begin{array}{l}\text { (Olszak, } \\
\text { 2012) }\end{array}$ & \\
\hline $\begin{array}{l}\text { Electronics } \\
\text { Purchasing }\end{array}$ & Points & $\mathrm{D}$ & $\mathrm{D}$ & $\mathrm{C}$ & $\begin{array}{l}\text { (AASHE, } \\
2016)\end{array}$ & $\begin{array}{l}\text { AASHE index (OP 12) that recognizes HEIs that are supporting markets for } \\
\text { environmentally preferable computers and other electronic products by } \\
\text { published and/or standardizes criteria (e.g. EPEAT). }\end{array}$ \\
\hline $\begin{array}{l}\text { Cleaning and } \\
\text { Janitorial } \\
\text { Purchasing }\end{array}$ & Points & $\mathrm{D}$ & $\mathrm{D}$ & $\mathrm{C}$ & $\begin{array}{l}\text { (AASHE, } \\
2016)\end{array}$ & $\begin{array}{l}\text { AASHE index (OP 13) that recognizes HEIs that purchase non-toxic cleaning } \\
\text { products (green cleaning) certified (e.g. Green Seal). }\end{array}$ \\
\hline $\begin{array}{l}\text { Office Paper } \\
\text { Purchasing }\end{array}$ & Points & $\mathrm{D}$ & $\mathrm{D}$ & $\mathrm{C}$ & $\begin{array}{l}\text { (AASHE, } \\
2016)\end{array}$ & $\begin{array}{l}\text { AASHE index (OP 14) that recognizes HEIs that purchase recycled-content and } \\
\text { third party certified office paper. }\end{array}$ \\
\hline
\end{tabular}


Table 15 Mobility indicators applicable to HEIs.

\begin{tabular}{|c|c|c|c|c|c|c|}
\hline Indicator & Unit & DPSIR & ABCDE & $\mathbf{S}$ or $\mathbf{C}$ & Reference & Observations \\
\hline Exceedances of air quality objectives due to traffic & & $\mathrm{S}$ & A & $\mathrm{S}$ & (EEA, 2014) & \\
\hline Road traffic, vehicles and networks & & $\mathrm{D}$ & A & $\mathrm{S}$ & (OCDE, 2015) & $\begin{array}{l}\text { This is a composite index that aggregates } \\
\text { traffic intensity and infrastructural density. } \\
\text { It is defined as a key indicator. }\end{array}$ \\
\hline Use of cleaner and alternative fuels & & $\mathrm{R}$ & $\mathrm{D}$ & $\mathrm{S}$ & $($ EEA, 2014) & \\
\hline Transport final energy consumption by mode & & $\mathrm{P}$ & A & $\mathrm{S}$ & $($ EEA, 2014) & \\
\hline Transport emissions of greenhouse gases & & $\mathrm{P}$ & A & $\mathrm{S}$ & $(\mathrm{EEA}, 2014)$ & \\
\hline Transport emissions of air pollutants & & $\mathrm{P}$ & A & $\mathrm{S}$ & $($ EEA, 2014) & \\
\hline Traffic noise: exposure and annoyance & & $\mathrm{I}$ & A & $\mathrm{S}$ & $($ EEA, 2014) & \\
\hline Occupancy rates of passenger vehicles & & $\mathrm{D}$ & A & $\mathrm{S}$ & $(\mathrm{EEA}, 2014)$ & \\
\hline Size of the vehicle fleet & & $\mathrm{P}$ & $\mathrm{C}$ & $\mathrm{S}$ & $($ EEA, 2014;) & \\
\hline Average age of the vehicle fleet & & $\mathrm{D}$ & A & $\mathrm{S}$ & $(\mathrm{EEA}, 2014)$ & \\
\hline $\begin{array}{l}\text { Proportion of vehicle fleet meeting certain } \\
\text { emission standards }\end{array}$ & & $\mathrm{D}$ & A & $\mathrm{S}$ & (EEA, 2014) & \\
\hline Campus fleet & Points & $\mathrm{D}$ & A & $\mathrm{S}$ & $\begin{array}{l}\text { (AASHE, } \\
\text { 2016) }\end{array}$ & $\begin{array}{l}\text { AASHE index (OP 15) that recognized } \\
\text { HEIs that use cleaner fuels and fuel- } \\
\text { efficient vehicles. }\end{array}$ \\
\hline $\begin{array}{l}\text { Significant environmental impacts of transporting } \\
\text { products and other goods and materials for the } \\
\text { organization's operations, and transporting } \\
\text { members of the workforce }\end{array}$ & & I & $\mathrm{P}$ & $\mathrm{C}$ & (GRI, 2013) & \\
\hline Student Commute Model Split & Points & $\mathrm{D}$ & A & $\mathrm{C}$ & $\begin{array}{l}\text { (AASHE, } \\
2016)\end{array}$ & $\begin{array}{l}\text { AASHE index (OP 16) that recognized } \\
\text { HEIs where students us preferable modes } \\
\text { of transportation to travel to and from } \\
\text { institution (e.g. Bicycling, carpooling). }\end{array}$ \\
\hline Employee Commute Model Split & Points & $\mathrm{D}$ & A & $\mathrm{C}$ & $\begin{array}{l}\text { (AASHE, } \\
2016)\end{array}$ & $\begin{array}{l}\text { AASHE index (OP 17) that recognized } \\
\text { HEIs where employees use preferable } \\
\text { modes of transportation to travel to and } \\
\text { from the institution (e.g. Bicycling, } \\
\text { carpooling). }\end{array}$ \\
\hline
\end{tabular}




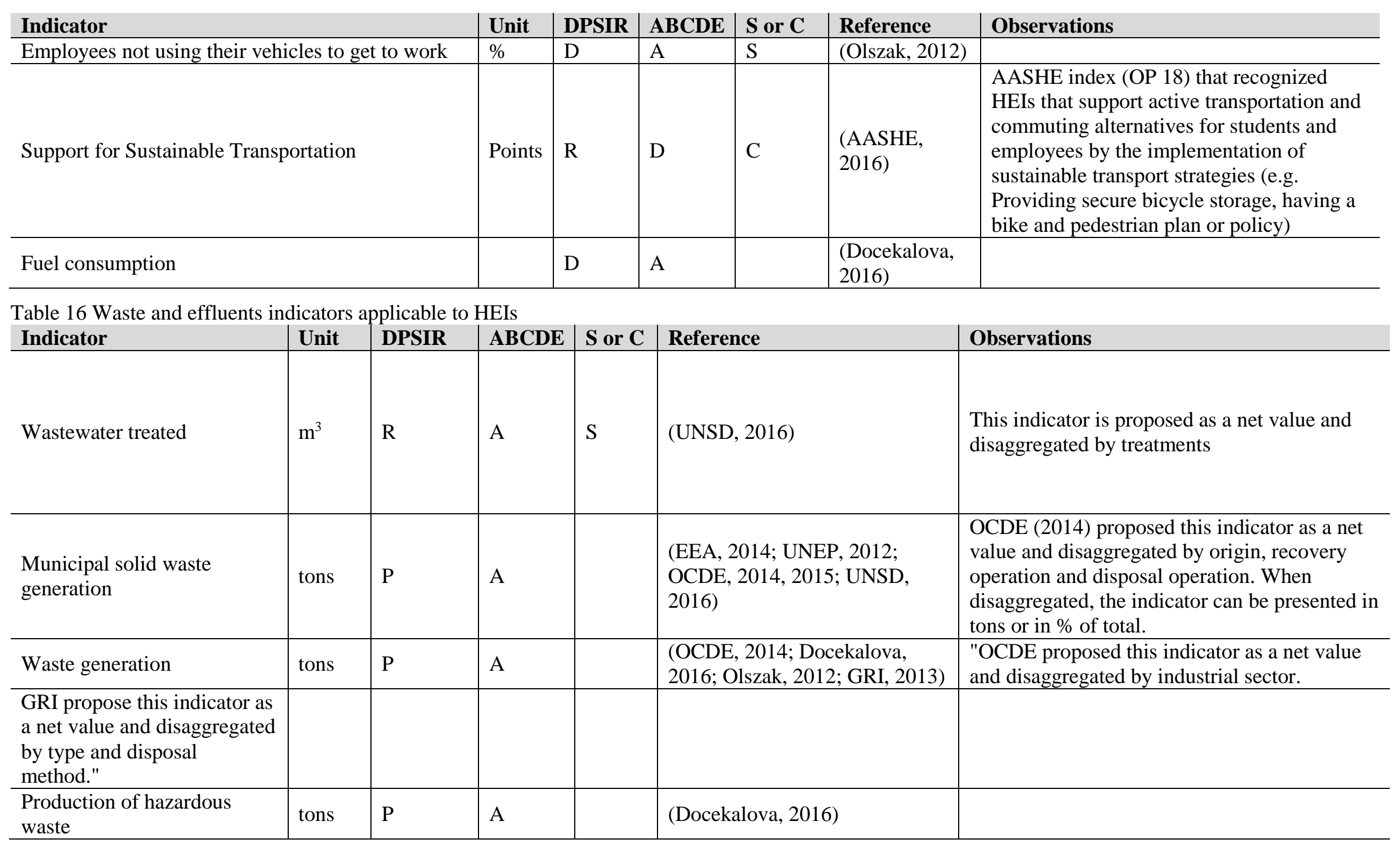




\begin{tabular}{|c|c|c|c|c|c|c|}
\hline Indicator & Unit & DPSIR & ABCDE & S or $\mathbf{C}$ & Reference & Observations \\
\hline $\begin{array}{l}\text { Waste electrical and } \\
\text { electronic equipment }\end{array}$ & tons & $\mathrm{R}$ & A & & (EEA, 2014) & \\
\hline Food waste & tons & $\mathrm{P}$ & A & & (OCDE, 2014) & $\begin{array}{l}\text { This indicator is proposed as a net value and } \\
\text { disaggregated by type of food (drkinks, edible, } \\
\text { fresh, frozen, etc.) and place of origin } \\
\text { (leftovers, kitchen caddy, etc.) }\end{array}$ \\
\hline $\begin{array}{l}\text { Waste Minimization and } \\
\text { Diversion }\end{array}$ & Points & $\mathrm{R}$ & $\mathrm{D}$ & & (AASHE, 2016) & $\begin{array}{l}\text { AASHE index (OP 19) that recognizes HEIs } \\
\text { that has implemented stroategies to reduce the } \\
\text { total ampunt of waste tenerated and diverts } \\
\text { materials from landfill or incinerator by } \\
\text { recycling, composting, donating, etc. }\end{array}$ \\
\hline $\begin{array}{l}\text { Construction and Demolition } \\
\text { Waste Diversion }\end{array}$ & Points & $\mathrm{D}$ & $\mathrm{D}$ & & (AASHE, 2016) & $\begin{array}{l}\text { AASHE index (OP 20) that recognizes HEIs } \\
\text { that have diverted construction and demolition } \\
\text { wastes. }\end{array}$ \\
\hline $\begin{array}{l}\text { Hazardous Waste } \\
\text { Management }\end{array}$ & Points & $\mathrm{R}$ & $\mathrm{D}$ & & (AASHE, 2016) & $\begin{array}{l}\text { AASHE index (OP 21) that recognizes HEIs } \\
\text { that has strategies to safely dispose of all } \\
\text { hazardous waste. Recicylin, reuse and } \\
\text { refurbish programs are also considered in this } \\
\text { index. }\end{array}$ \\
\hline $\begin{array}{l}\text { Composition of municipal } \\
\text { waste }\end{array}$ & & $\mathrm{D}$ & A & & (UNSD, 2016) & \\
\hline Wastewater discharged & $\mathrm{m}^{3}$ & $\mathrm{D}$ & A & & (Docekalova, 2016; GRI, 2013) & $\begin{array}{l}\text { GRI propose this indicator as a net value and } \\
\text { disaggregated by quality and destination. }\end{array}$ \\
\hline Significant spill & $\mathrm{m}^{3}$ & $\mathrm{P}$ & A & $\mathrm{S}$ & (GRI, 2013) & $\begin{array}{l}\text { GRI propose this indicator disaggregated by } \\
\text { composition of spill. }\end{array}$ \\
\hline
\end{tabular}


Table 17 Water indicators applicable to HEIs

\begin{tabular}{|c|c|c|c|c|c|c|}
\hline Indicator & Unit & DPSIR & ABCDE & $\begin{array}{l}\text { S } \\
\text { or } \\
\text { C }\end{array}$ & Reference & Observations \\
\hline $\begin{array}{l}\text { Urban wastewater } \\
\text { treatment }\end{array}$ & & $\mathrm{R}$ & A & $\mathrm{S}$ & $\begin{array}{l}\text { (EEA, 2014; OCDE, 2015; } \\
\text { UNSD, 2016) }\end{array}$ & \\
\hline $\begin{array}{l}\text { Water footprint per } \\
\text { capita of national } \\
\text { production }\end{array}$ & $\begin{array}{l}\mathrm{m}^{3} \text { per } \\
\text { year } \\
\text { per } \\
\text { person }\end{array}$ & $\mathrm{P}$ & B & $\mathrm{S}$ & (UNEP, 2012) & \\
\hline $\begin{array}{l}\text { Population } \\
\text { connected to } \\
\text { independent } \\
\text { treatment }\end{array}$ & & $\mathrm{D}$ & $\mathrm{D}$ & $\mathrm{S}$ & (OCDE, 2014; UNSD; 2016) & $\begin{array}{l}\text { OCDE (2014) propose this indicator as a net value and } \\
\text { disaggregated by sectors in } \mathrm{m} 3 \text { and related to population. }\end{array}$ \\
\hline Water consumption & $\mathrm{m}^{3}$ & $\mathrm{D}$ & A & & $\begin{array}{l}\text { (UNSD, 2016; Docekalova, 2016; } \\
\text { Moldan et al., 2012; Olszak, } \\
\text { 2012; GRI, 2013) }\end{array}$ & $\begin{array}{l}\text { GRI propose this indicator as a net value and } \\
\text { disaggregated by source. }\end{array}$ \\
\hline \multirow{2}{*}{$\begin{array}{l}\text { Use of freshwater } \\
\text { resources }\end{array}$} & $\mathrm{m}^{3}$ & \multirow[b]{2}{*}{$\mathrm{P}$} & \multirow[b]{2}{*}{ A } & & \multirow[b]{2}{*}{ (EEA, 2014; OCDE, 2014, 2015) } & \multirow{2}{*}{$\begin{array}{l}\text { OCDE (2014) propose this indicator as a net value and } \\
\text { disaggregated by sectors in } \mathrm{m} 3 \text { and related to population. } \\
\text { UNSD propose this indicator disaggregated by source." }\end{array}$} \\
\hline & $\begin{array}{l}\mathrm{m}^{3} \text { per } \\
\text { capita }\end{array}$ & & & & & \\
\hline $\begin{array}{l}\text { Generation and } \\
\text { discharge of } \\
\text { wastewater }\end{array}$ & $\mathrm{m}^{3}$ & $\mathrm{P}$ & A & & (OCDE, 2014, UNSD, 2016) & $\begin{array}{l}\text { OCDE (2014) propose this indicator as a net value and } \\
\text { discriminated in household and industry }\end{array}$ \\
\hline Water Use & Points & $\mathrm{D}$ & $\mathrm{C}$ & & (AASHE, 2016) & $\begin{array}{l}\text { AASHE index (OP 22) that recognizes HEIs that has } \\
\text { reduced water use (potable and non-potable). }\end{array}$ \\
\hline $\begin{array}{l}\text { Rainwater } \\
\text { Management }\end{array}$ & Points & $\mathrm{R}$ & $\mathrm{D}$ & & (AASHE, 2016) & $\begin{array}{l}\text { AASHE index (OP 23) that recognizes HEIs with } \\
\text { policies and programs to reduce storm water runoff and } \\
\text { resultant water pollution treating rainwater as a resource. }\end{array}$ \\
\hline Evapotranspiration & $\mathrm{m}^{3}$ & $\mathrm{P}$ & A & & (OCDE, 2014) & $\begin{array}{l}\text { Indicators in averages to assess freshwater resources in } \\
\text { long-term. }\end{array}$ \\
\hline $\begin{array}{l}\text { Freshwater } 95 \% \text { of } \\
\text { time }\end{array}$ & $\mathrm{m}^{3}$ & $\mathrm{P}$ & A & & (OCDE, 2014) & $\begin{array}{l}\text { Indicators in averages to assess freshwater resources in } \\
\text { long-term. }\end{array}$ \\
\hline
\end{tabular}




\begin{tabular}{l|l|l|l|l|l|l} 
Indicator & Unit & DPSIR & ABCDE & $\begin{array}{l}\text { or } \\
\mathbf{C}\end{array}$ & Reference & Observations \\
\hline $\begin{array}{l}\text { Groundwater for } \\
\text { abstraction }\end{array}$ & $\mathrm{m}^{3}$ & $\mathrm{P}$ & $\mathrm{A}$ & & (OCDE, 2014; UNSD, 2016) & $\begin{array}{l}\text { Indicators in averages to assess freshwater resources in } \\
\text { long-term. }\end{array}$ \\
\hline $\begin{array}{l}\text { Inflows } \\
\text { Internal resources }\end{array}$ & $\mathrm{m}^{3}$ & $\mathrm{P}$ & $\mathrm{A}$ & & (OCDE, 2014) & $\begin{array}{l}\text { Indicators in averages to assess freshwater resources in } \\
\text { long-term. }\end{array}$ \\
\hline Outflow total & $\mathrm{m}^{3}$ & $\mathrm{P}$ & $\mathrm{A}$ & & (OCDE, 2014) & Indicators in averages to assess freshwater resources in \\
\hline long-term.
\end{tabular}




\section{Annex 2. Validation method}

Key good-practice factors and meta-performance evaluation indicators are described, following Ramos and Caeiro (2010) proposal for each level.

Table 18 presents the proposal for level 1: Performance of KPIs system: planning and methodological approach. Table 19 presents level 2 key good-practices, performance of KPIs at the implementation and operation stage. Observations are included in both tables for a better interpretation.

\begin{tabular}{|c|c|c|c|}
\hline $\begin{array}{l}\text { Key good-practice } \\
\text { factor }\end{array}$ & $\begin{array}{c}\text { Meta-performance } \\
\text { evaluation indicators }\end{array}$ & Possible answers & Observation \\
\hline Objectives & $\begin{array}{l}\text { Identification of specific } \\
\text { targets }\end{array}$ & $\begin{array}{l}\text { Yes / No } \\
+ \text { specifications }\end{array}$ & $\begin{array}{l}\text { It is vital to verify that the set of KPIs are consistent with the motivation and } \\
\text { the specific goals of the assessment. }\end{array}$ \\
\hline \multirow{2}{*}{$\begin{array}{l}\text { Management } \\
\text { framework }\end{array}$} & $\begin{array}{l}\text { Identification of a } \\
\text { management model }\end{array}$ & $\begin{array}{l}\text { Yes / No } \\
+ \text { specifications }\end{array}$ & \multirow{2}{*}{$\begin{array}{l}\text { Although KPIs are aimed to be used by any decision maker, identifying the } \\
\text { management model and the author of the set of KPI gives them stability. }\end{array}$} \\
\hline & Cooperation & $\begin{array}{l}\text { Yes / No } \\
+ \text { specifications }\end{array}$ & \\
\hline $\begin{array}{l}\text { Indicator structure } \\
\text { and organization }\end{array}$ & $\begin{array}{l}\text { Use of conceptual } \\
\text { framework }\end{array}$ & $\begin{array}{l}\text { Yes / No } \\
+ \text { specifications }\end{array}$ & $\begin{array}{l}\text { The use of DPSIR framework, as suggested, would result in a better } \\
\text { description and transparency of the definition procedure itself and the use of } \\
\text { the KPIs set. }\end{array}$ \\
\hline \multirow{2}{*}{$\begin{array}{l}\text { Regularity and } \\
\text { review process }\end{array}$} & $\begin{array}{l}\text { Revision of the EMS } \\
\text { processes }\end{array}$ & $\begin{array}{l}\text { Yes / No } \\
+ \text { specifications }\end{array}$ & \multirow{2}{*}{$\begin{array}{l}\text { An annual assessment, review and report of the indicators is suggested } \\
\text { following the proposal procedure. Including the definition of KPIs in the } \\
\text { EMS review would add coherency to the linkage with the system. }\end{array}$} \\
\hline & $\begin{array}{l}\text { Regular updating and } \\
\text { reporting }\end{array}$ & $\begin{array}{l}\text { Yes / No } \\
+ \text { specifications }\end{array}$ & \\
\hline $\begin{array}{l}\text { Promotion and } \\
\text { communication }\end{array}$ & $\begin{array}{l}\text { Reporting and } \\
\text { communication to } \\
\text { stakeholders }\end{array}$ & $\begin{array}{l}\text { Yes / No } \\
+ \text { specifications }\end{array}$ & $\begin{array}{l}\text { KPIs should be reported within the annual environmental declaration of the } \\
\text { HEI and properly identified in the communication channel with stakeholders, } \\
\text { if any. }\end{array}$ \\
\hline $\begin{array}{l}\text { Decision-makers' } \\
\text { and stakeholders' } \\
\text { responses }\end{array}$ & $\begin{array}{l}\text { Linkage between KPIs and } \\
\text { policies, plans and } \\
\text { programs. }\end{array}$ & $\begin{array}{l}\text { Yes / No } \\
+ \text { specifications }\end{array}$ & $\begin{array}{l}\text { Environmental policies, the list of EA and the know-how of assessors should } \\
\text { be basis of KPIs definition process. }\end{array}$ \\
\hline
\end{tabular}


Table 19 Level 2 key good-practice factors and its meta-performance evaluation indicators for environmental KPIs for HEIs

\begin{tabular}{|c|c|c|c|}
\hline $\begin{array}{l}\text { Key good- } \\
\text { practice factor }\end{array}$ & $\begin{array}{c}\text { Meta-performance } \\
\text { evaluation indicators }\end{array}$ & Possible answers & Observation \\
\hline $\begin{array}{l}\text { Conceptual } \\
\text { coherence }\end{array}$ & $\begin{array}{l}\text { Indicators that are not } \\
\text { supported in published } \\
\text { scientific or technical work }\end{array}$ & Percentage & $\begin{array}{l}\text { A high percentage of indicators without scientific support endanger the } \\
\text { system and the action planes developed based on the set of KPIs. }\end{array}$ \\
\hline $\begin{array}{l}\text { Methodological } \\
\text { approach and } \\
\text { data collection }\end{array}$ & $\begin{array}{l}\text { Indicators with clear method } \\
\text { for data analysis and collection }\end{array}$ & Percentage & $\begin{array}{l}\text { The procedure to assess each KPI shall be described in its definition } \\
\text { unambiguously. }\end{array}$ \\
\hline \multirow{3}{*}{ Quality control } & $\begin{array}{l}\text { Identification of the means and } \\
\text { methods to audit indicator } \\
\text { quality }\end{array}$ & $\begin{array}{l}\text { Yes / No } \\
+ \text { specifications }\end{array}$ & \multirow{3}{*}{$\begin{array}{l}\text { The quality control of the indicators is as important as its validation. This } \\
\text { good practice is strongly linked to the previous as availability of quality } \\
\text { data is required for a high-quality result. } \\
\text { No indicator should be used without considering the uncertainty of the raw } \\
\text { data when applicable. When estimations are needed, the uncertainty of the } \\
\text { procedure of estimation should accompany the value of the indicator. }\end{array}$} \\
\hline & Analytical measurements. & $\begin{array}{l}\text { No. of indicators } \\
\text { assessed with direct } \\
\text { measurement. }\end{array}$ & \\
\hline & Uncertainty analysis. & Results by indicator & \\
\hline \multirow{2}{*}{$\begin{array}{l}\text { Logistical } \\
\text { requirement } \\
\text { and } \\
\text { information } \\
\text { management }\end{array}$} & $\begin{array}{l}\text { Identification of logistics } \\
\text { requirements for each } \\
\text { indicator. }\end{array}$ & $\begin{array}{l}\text { Yes / No } \\
+ \text { specifications }\end{array}$ & \multirow{2}{*}{$\begin{array}{l}\text { As KPIs are supposed to be integrated in the EMS already running, the } \\
\text { logistics should not be significantly affected. However, the data quality } \\
\text { requirements may demand additional resources. Regarding information } \\
\text { management, EMAS required a detailed procedure to manage information } \\
\text { internal and externally while ISO restrict the requirement to the internal } \\
\text { scenario. In any case, both for EMAS and ISO EMS, managing information } \\
\text { should not be a problem. }\end{array}$} \\
\hline & $\begin{array}{l}\text { Identification of information } \\
\text { management procedures for } \\
\text { each indicator. }\end{array}$ & $\begin{array}{l}\text { Yes / No } \\
+ \text { specifications }\end{array}$ & \\
\hline $\begin{array}{l}\text { Understanding } \\
\text { and utility }\end{array}$ & $\begin{array}{l}\text { Indicators easily } \\
\text { understandable by decision- } \\
\text { makers }\end{array}$ & Percentage & $\begin{array}{l}\text { One of the principal reasons of defining KPIs to assess environmental } \\
\text { performance of HEIs is having understandable and easy to measure } \\
\text { indicators that provides key information for an effective and efficient } \\
\text { decision-making toward a better environmental performance. Check that } \\
\text { indicators are key is essential. }\end{array}$ \\
\hline
\end{tabular}

